\title{
EFFECT OF THE HARVEST SEASON ON PHENOLIC COMPOSITION AND OENOLOGICAL PARAMETERS OF GRAPES AND WINES CV. 'TOURIGA NACIONAL' (Vitis vinifera L.) PRODUCED UNDER TROPICAL SEMI-ARID CLIMATE, IN THE STATE OF PERNAMBUCO, BRAZIL
}

\author{
EFEITO DA ÉPOCA DE COLHEITA NA COMPOSIÇÃO FENÓLICA E PARÂMETROS ENOLÓGICOS DE \\ UVAS E VINHOS CV. 'TOURIGA NACIONAL' (Vitis vinifera L.) PRODUZIDOS SOB CLIMA TROPICAL \\ SEMIÁRIDO, NO ESTADO DE PERNAMBUCO, BRASIL
}

\author{
Juliane Barreto de Oliveira ${ }^{1,4^{*}}$, Diana Lemos Faria ${ }^{1}$, Daniel Fernandes Duarte ${ }^{1}$, Ricardo Egipto ${ }^{1,2}$, Olga Laureano ${ }^{1}$, \\ Rogério de Castro ${ }^{1}$, Giuliano Elias Pereira ${ }^{3}$, Jorge Manuel Ricardo-da-Silva ${ }^{1}$
}

\author{
${ }^{1}$ LEAF - Linking Landscape, Environment, Agriculture and Food. Instituto Superior de Agronomia, Universidade de Lisboa, Tapada da Ajuda, 1349-017 \\ Lisboa, Portugal. \\ ${ }^{2}$ INIAV, I.P., Pólo de Dois Portos, Quinta da Almoínha, 2565-191 Dois Portos, Portugal. \\ ${ }^{3}$ Embrapa Uva e Vinho/Semiárido, BR-428, Km 152, s/n - Zona Rural, Petrolina - PE, 56302-970, Brasil. \\ ${ }^{4} \mathrm{PhD}$ student in Food Engineering.
}

* Corresponding author: Tel.: +351 213652102, email: juliane.barreto@hotmail.com

\section{SUMMARY}

The northeastern region of São Francisco Valley is the third largest wine producer in Brazil, differentiated by the production of at least two harvests per year, generally in the first and second semesters, respectively. The productive cycle of the vine in the first semester is higher than in the second semester, mainly due to differences in temperature, with maximum and average temperatures of approximately $30{ }^{\circ} \mathrm{C}$ and $26^{\circ} \mathrm{C}$, respectively. Second semester is characterized by higher temperatures (summer season) and that promote a rapid maturation of the grapes. The objective of this work was to evaluate the phenolic composition, other oenological parameters and the sensorial profile of grapes and wines of cv. 'Touriga Nacional' (Vitis vinifera L.), characterizing grapes and wines from four harvest seasons, two of them referring to the first half of the year and two referring to the second half of the year, using a broad analytical approach. The experimental design consisted of three randomized blocks, with sixty plants marked in different lines and positions (twenty plants in each block at the beginning, middle and end of the vineyard). The results showed that there was a harvesting effect for some of the grape chemical compounds (monomeric anthocyanins, organic acids, condensed tannins and monomeric flavanols, for example) as well as in wines (calcium, monomeric anthocyanins, condensed tannins and monomeric flavanols). Regarding the sensorial profile of the wines, it was possible to observe that higher scores were attributed to floral aroma in wines from the first harvest (first half of the year). Fruity, spice and empyreumatic aromas were higher in wines from second harvest season (second half of the year). For other attributes, there was a tendency for higher variations between the period of study (2014 - 2017) than between the harvest seasons.

\section{RESUMO}

A região Nordeste do Vale do São Francisco é a terceira maior produtora de vinho do Brasil, diferenciada pela produção de pelo menos duas vindimas por ano, geralmente no primeiro e segundo semestres, respetivamente. $\mathrm{O}$ ciclo produtivo da videira no primeiro semestre é maior do que no segundo semestre, principalmente devido as diferenças de temperaturas, com temperaturas máxima e média de aproximadamente $30^{\circ} \mathrm{C}$ e $26^{\circ} \mathrm{C}$, respetivamente. $\mathrm{O}$ segundo semestre é caracterizado por temperaturas mais altas (época de verão) que promovem uma rápida maturação da uva. O objetivo deste trabalho foi avaliar a composição fenólica, outros parâmetros enológicos e o perfil sensorial de uvas e vinhos da cv. 'Touriga Nacional' (Vitis vinifera L.), caracterizando uvas e vinhos de quatro épocas de colheitas, sendo duas referentes ao primeiro semestre e duas referentes ao segundo semestre do ano, utilizando para isso uma ampla abordagem analítica. O delineamento experimental consistiu em três blocos casualizados, com sessenta plantas marcadas em diferentes linhas e posições (vinte plantas em cada bloco, no início, meio e fim da vinha). Os resultados mostraram que houve um efeito da época de colheita para alguns dos compostos da uva (antocianinas monoméricas, ácidos orgânicos, taninos condensados e flavanóis monoméricos, por exemplo) e nos vinhos (cálcio, antocianinas monoméricas, taninos condensados e flavanóis monoméricos). Em relação ao perfil sensorial dos vinhos, foi possível observar que maiores pontuações foram atribuídas ao aroma floral nos vinhos da primeira vindima (primeiro semestre do ano). Aromas frutados, de especiarias e empireumáticos foram maiores nos vinhos da segunda época de colheita (segundo semestre do ano). Para os demais atributos, houve uma tendência para maiores variações entre os anos de estudo do que entre as vindimas.

Key words: phenolic compounds, red wines, sensory profile, Touriga Nacional, tropical semi-arid grape.

Palavras-chave: compostos fenólicos, vinhos tintos, perfil sensorial, Touriga Nacional, uva tropical semiárida. 145

This is an Open Access article distributed under the terms of the Creative Commons Attribution License (http://creativecommons.org/licenses/by/4.0), which permits unrestricted use, distribution, and reproduction in any medium, provided the original work is properly cited. 


\section{INTRODUCTION}

Tropical viticulture is typical from regions where minimum temperatures are not low enough to induce the vine to dormancy. The vine grows continuously and with the use of appropriate technology is possible to obtain two or more harvests per year in the same vineyard. The harvest season can be scheduled for any day of the year. The main poles of tropical viticulture in Brazil are Submédio São Francisco Valley, northwest Paulista and north of Minas Gerais (mainly for table grapes). In recent years, tropical viticulture has expanded in several other States, such as Espírito Santo, Mato Grosso do Sul, Mato Grosso, Goiás, Rondônia, Ceará and Piauí (Camargo et al., 2011).

The term "Terroir" is diverse and involve several factors that influence the composition of the grapes and consequently of the wines from a specific region. According to some authors, the environmental characteristics (climate and soil conditions) and cultural practices applied in the vineyards are important examples of these factors (Downey et al., 2006; Gutiérrez-Gamboa et al., 2017, GutiérrezGamboa and Moreno-Simunovic, 2018).

Submédio São Francisco Valley, situated between the States of Bahia and Pernambuco, is recognized as the third region for the production of fine wines, after Serra Gaúcha and Campanha Gaúcha in the State of Rio Grande do Sul. This "Terroir" is located in places $350 \mathrm{~m} \mathrm{high,} \mathrm{in} \mathrm{average,} \mathrm{where} \mathrm{is} \mathrm{present} \mathrm{flat}$ productive areas. Those have typical landscape of northeastern sertão, with an annual temperature of 26 ${ }^{\circ} \mathrm{C}$ in average and intra-annual variability. This region has a tropical semi-arid climate that allows the production of grapes in non-conventional periods of the year, such as the winter, in even three harvests. The sun incidence and high temperatures, associated with irrigation that must be done allow these special conditions, making this region unique in the world (Pereira et al., 2008, Pereira et al., 2011).

Vitis vinifera L. cv. 'Touriga Nacional' is an important Portuguese autochthon red grape variety (Böhm, 2007). It is adapted to all types of soils although it requires high temperatures and sunshine. In addition, it behaves well in most part of the rootstocks, as long as they have a fertile soil and availability of water (IVV, 2017). This variety has presented good adaptation in the edaphoclimatic conditions of São Francisco Submédio Valley, being one of the most used to produce monovarietal wines, as well as added in blends with other grape varieties.
Some studies were carried out in this region to evaluate the phenolic composition of grapes and wines at different harvest seasons. Santos et al. (2007) evaluated the oenological potential of the cultivars 'Alfrocheiro', 'Deckrot' and 'Tempranillo' in two different seasons of the year. Their studies concluded that there were significant differences on the oenological potential between different varieties when harvested in different seasons. In addition, Rosatti et al. (2013) have studied the maturation of 'Barbera' grapes from organic production in two productive cycles. These authors have concluded that this variety presents some variance in between cycles along the year. This grapes variety presented duration of the first productive cycle (first half of the year) between 82 up to 92 days after fruiting and the second productive cycle (second semester) between 47 up to 57 days after fruiting. Second cycle has shown higher concentrations of bioactive compounds. Oliveira et al. (2014) have analysed the influence of grape maturation stage on the physicochemical composition and antioxidant activity of the 'Syrah' wine manufactured in the harvest of the second productive cycle of the year. The results of their studies have demonstrated that on the second cycle of production the total anthocyanins, total phenols and antioxidant activity has increased in wines made from grapes harvested between 120 and 128 days after pruning. Lima and Leão (2015) studied the content of phenolic compounds and antioxidant potential of 'Syrah' grapes under the influence of leaf removal and trimming during productive cycle on the first semester. They concluded that 'Syrah' grapes from semi-arid tropical conditions submitted to the treatment described presented higher concentrations of total anthocyanins and antioxidant activity. Lima et al. (2015) evaluated the main physical and chemical characteristics of 'Syrah' grapes harvested on tropical semi-arid region of São Francisco Valley, at different times and their relationship with analytical characteristics of resulting wines. They have concluded that 'Syrah' grapes harvested between 126 and 133 days after pruning in the first harvest season presented better oenological potential for the manufacture of red wine.

Due to the lack of information on grape and wine chemical composition from cv. 'Touriga Nacional', produced in tropical semi-arid region of São Francisco Valley at different harvest seasons, the aim of this work was to characterize the phenolic composition and other oenologic parameters of grapes and wines, as well as their sensorial profile in four harvest seasons, using a broad analytical approach. 


\section{MATERIAL AND METHODS}

\section{Description of vineyard area and their harvests}

The area of study is located in the municipality of Lagoa Grande, State of Pernambuco, between latitude parallels $8-9^{\circ}$ in the Southern Hemisphere and with an altitude of $350 \mathrm{~m}$. The soil is classified as red-yellow Argissolo, usually with medium natural fertility. The region's climate is characterized in first semester of the year as very warm, with warm nights and moderate drought. In second semester, the temperature is very high, inclusive during the night and severe drought (Tonietto et al., 2012) and natural climatic conditions can change the class of wine according with period of the year during which the grapes are being produced. It has been collected climatic data according with the period of this study and the results are presented in Figure 1.

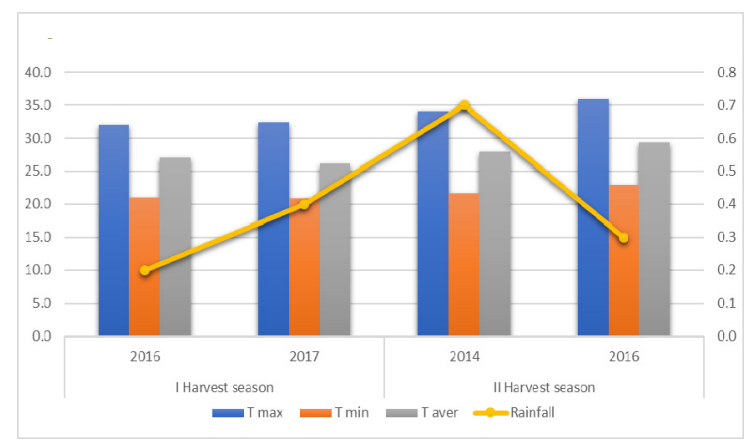

Figure 1. Meteorological data relative to the harvest seasons and years of study, in the state of Pernambuco, tropical semi-arid region of Brazil.

Dados meteorológicos relativos às épocas de colheita e anos de estudos, no estado de Pernambuco, em região tropical semiárida do Brasil.

The vineyard was conducted in a single wire trellis system, being the planting density of 3.333 vines/ha ( $3 \mathrm{~m}$ between rows and $1 \mathrm{~m}$ in each row). The orientation of these lines was North-South. Irrigation system utilized was by drip irrigation. The variety used in the study was 'Touriga Nacional' (Vitis vinifera L.). The vines were grafted onto 1103 Paulsen rootstock. Plants had 11 years old and due to the conditions of the region it was possible to harvest grapes twice a year (first and second semesters). The experimental design was a randomized three blocks, where sixty plants were marked in different lines and positions (twenty plants in each block, at the beginning, middle and end of the vineyard).

The first harvest season was made in December 2014 (corresponding of second harvest of 2014), the second in July 2016 (first harvest of the year), the third in
January 2016 and the fourth in July 2017. The decision of the harvest point was defined by the winery. In each harvest, approximately forty kilos of grapes has been collected manually and stored at low temperature $\left(0^{\circ} \mathrm{C}\right)$ during 24 hours until vinification.

\section{Methods used to extract compounds from the grapes}

The grapes were randomly selected for analysis in different plants and parts of the bunch (beginning, middle, end, interior and exterior), following two methodologies of extraction of the phenolic compounds.

The first one is proposed by Carbonneau and Champagnol (1993). The extract was obtained from the maceration of skins and seeds, during 24 hours at $20{ }^{\circ} \mathrm{C}$, using as solvents ethanol $(96 \%)$ and tartaric acid solution at $\mathrm{pH}$ 3.2. Then, the extract was centrifuged at $3500 \mathrm{rpm}$ for 10 to 15 minutes, before being used.

In the second extraction method, skins, pulps and seeds were separated, weighed and the phenolic compounds extracted in each part according to the method described by Bourzeix et al. (1986) using solvents of different polarities (methanol, water and acetone) and with different contact times for successive macerations. The first extraction takes place at $-24^{\circ} \mathrm{C}$ overnight (using methanol), then further macerations were carried out under a nitrogen atmosphere, according to the following procedure: $4 \mathrm{~h}$ at room temperature, with a solution of methanol and water $(80: 20 \mathrm{v} / \mathrm{v}) ; 4 \mathrm{~h}$ at room temperature, with a solution of methanol and water $(50: 50 \mathrm{v} / \mathrm{v}) ; 15 \mathrm{~h}$ at $24{ }^{\circ} \mathrm{C}$ with distilled water; $1 \mathrm{~h}$ at room temperature, with a solution of acetone and water $(75: 25 \mathrm{v} / \mathrm{v})$. At each extraction the obtained liquid must was collected and stored $\left(4^{\circ} \mathrm{C}\right)$ under nitrogen atmosphere.

Routine and spectrophotometric analytical methods applied to grapes analysis

\section{Technological parameters}

The technological parameters were obtained from the pulp: $\mathrm{pH}$, total soluble solids, total acidity, as well as tartaric acid and malic acid. These parameters were evaluated according to the methodologies described by the International Organization of Vine and Wines (OIV, 2014).

\section{Spectrophotometric analyses}

The analyses were performed using the extracts of the skins and seeds, in order to determine total phenols (Ribéreau-Gayon, 1970), non-flavonoid and flavonoid phenols (Kramling and Singleton, 1969), total anthocyanins (Ribéreau-Gayon and Stonestreet, 
1965), color intensity and tonality (OIV, 2014). Tanning power (De Freitas and Mateus, 2001) was also evaluated using a turbidimeter. With the individual extracts of the skins, pulps and seeds of the berries, the fractionation of flavanols as a function of their molecular weight (Sun et al., 1998a,b) has been analysed.

\section{Vinification of monovarietal wines}

After the harvest of grapes at Santa Maria farm (Global Wines), experimental wines were made at Embrapa Semi-Arid Oenology Laboratory (Petrolina, Brazil). The microvinification process was performed with a composite sample of forty kilograms per each harvest season.

Wine made has followed the traditional vinification for red wines: after harvest, the grapes were kept in a cold chamber $\left(0-5{ }^{\circ} \mathrm{C}\right)$ until vinification. Then the grapes were removed from the stalks with semiautomatic equipment (Model DH150-DA, ReciferBrazil). To induce the alcoholic fermentation, 50 $\mathrm{mg} / \mathrm{L}$ of sulfur dioxide and $20 \mathrm{~g} / \mathrm{hL}$ of yeast (Saccharomyces cerevisiae, bayanus variety, Everintec, Italy) were added. At this stage, the temperature was between $22{ }^{\circ} \mathrm{C}$ and $25{ }^{\circ} \mathrm{C}$. The "remontage" was performed once a day with rack and return modality. The maceration time and the contact of the solid parts with the liquid was uniform in all treatments with made during 7 days (with the objective of maintain the homogeneity of the phenolic compounds extraction). The end of the alcoholic fermentation was identified through the stability of the density and analysis of alcohol content. Malolactic fermentation was performed without addition of bacteria, and has been done only with native species. For this fermentation, temperature has varied between $16{ }^{\circ} \mathrm{C}$ up to $18{ }^{\circ} \mathrm{C}$. The ending point has been identified through chromatography paper (OIV, 2014). The tartaric stabilization in cold (0-5 ${ }^{\circ} \mathrm{C}$ ) has happened during 30 days. Then, the amount of sulfur dioxide has been corrected. Wines were bottled in green bottles and the head space was replaced with nitrogen before closing.

\section{Wines physicochemical characterization}

The wines were analyzed six months after the end of the tartaric stabilization. The following parameters have been analysed: alcohol content, residual sugar, free and total sulfur dioxide, volatile and total acidity, $\mathrm{pH}$, dry extract, and minerals (potassium and calcium) following the methodologies proposed by International Organization of Vine and Wine (OIV, 2014).
The colorimetric parameters determined in this study were: total anthocyanins (Ribéreau-Gayon and Stonestreet, 1965); colored anthocyanin (Somers and Evans, 1977); total phenols (Ribéreau-Gayon, 1970); flavonoid and non-flavonoid phenols (Kramling and Singleton, 1969); color due to copigmentation (Boulton, 2001); color intensity and tonality (OIV, 2014); total and polymeric pigments (Somers, 1971; Somers and Evans, 1977) and tanning power (De Freitas and Mateus, 2001). These parameters have been determined according with methods proposed and described in the literature.

Separation and quantification of individual monomeric anthocyanins by HPLC

The identification and quantification of individual monomeric anthocyanins was carried out using HPLC equipment (Perkin-Elmer, USA), consisting of pump (Series 200) and detector (LC95 Uv/Visible), with a column C18 (250 mm x $4 \mathrm{~mm}$ ) of reverse phase with $5 \mu \mathrm{m}$ of compaction, protected by a pre-column consisting of the same material, both from LichroCart (Merck, Germany). The solvents consisted of: A (40\% formic acid and $60 \%$ bidistilled water), B (acetonitrile p.a.) and $\mathrm{C}$ (bidistilled water). Methanol/water $(50: 50 \mathrm{v} / \mathrm{v})$ was used to wash the column after the analyses.

The initial conditions used in HPLC were the following: $25 \% \mathrm{~A}, 6 \% \mathrm{~B}$ and $69 \% \mathrm{C}$ for 15 minutes, followed by a $25 \%$ linear gradient of A, $25.5 \%$ B and $49.5 \% \mathrm{C}$ for 70 minutes. The finish has happened after 20 minutes with the addition of $25 \% \mathrm{~A}, 25.5 \% \mathrm{~B}$ and $49.5 \% \mathrm{C}$. The flow was $0.7 \mathrm{~mL} / \mathrm{min}$, and detection has been made at $520 \mathrm{~nm}$. Both samples and the solvents were filtered under the same conditions. The volume injected was $20 \mu 1$ (samples extract have been previously separated from the grapes or wine, following by filtration). The analyses have been performed in triplicate. The column temperature was $30{ }^{\circ} \mathrm{C}$, controlled by a column oven. Fourteen individual anthocyanin molecules have been separated and quantified. Identification has followed the method described by Roggero et. al. (1986) and quantification was done based on a standard curve obtained with malvidin 3 - $O$-glucoside $\left(\mathrm{R}^{2}=0.981\right)$. Grape and wine extracts have been analysed in triplicate.

Fractionation of low molecular weight flavanols on a polyamide column chromatography and further quantification by HPLC

Five milliliters of individual extracts (skins and seeds samples) and wines were fractionated on a polyamide column (Macherey-Nagel, Germany) as described by Ricardo-da-Silva et al. (1990). Phenolic acids were 
first eluted with $80 \mathrm{~mL}$ of phosphate buffer, $\mathrm{pH}$ 7.0. The monomeric flavanols were eluted with $50 \mathrm{~mL}$ of ethyl acetate/water $(30: 70 \mathrm{v} / \mathrm{v})$ and oligomeric procyanidins with $50 \mathrm{~mL}$ of acetone/water (75:25 $\mathrm{v} / \mathrm{v})$. The fractions were brought to dryness, dissolved in $1.2 \mathrm{~mL}$ of methanol/water $(50: 50 \mathrm{v} / \mathrm{v})$, filtered through a $0.45 \mu \mathrm{m}$ membrane (Whatman, USA) and finally injected onto the HPLC column. Following the procedure described above a new polyamide column was used for each sample.

The equipment used for HPLC analysis consisted of a UV-Vis detector (Waters 2487) and a L-7100 pump (Waters, USA). The separation was performed on a Lichrosphere C18 reverse phase column (Merck, Germany) $250 \mathrm{~mm} \times 4.6 \mathrm{~mm} \times 5 \mu \mathrm{m}$, at room temperature. For monomeric flavan-3-ols, the gradient consisting of solvent $\mathrm{A}$ (water/acetic acid, 97.5:2.5 v/v) and solvent B (acetonitrile / solvent A, $80: 20 \mathrm{v} / \mathrm{v}$ ) was used. The elution was performed at a flow rate of $0.9 \mathrm{~mL} / \mathrm{min}$ as follows: $7-25 \%$ B linear from 0 to 31 minutes, followed by washing (methanol/water, 50:50 v/v) $32-50 \mathrm{~min}$ and the rebalancing of the column from 51 to 65 min under initial gradient conditions. For oligomeric procyanidins, the solvents $\mathrm{A}$ (bidistilled water) and $\mathrm{B}$ (bidistilled water/acetic acid, 90:10 v/v) were used. The elution was performed at a flow rate of 1.0 $\mathrm{mL} / \mathrm{min}$ as follows: $10-70 \%$ linear B 0-45 min, 70$90 \%$ linear B $45-70 \mathrm{~min}, 90 \%$ B isocratic 70-82 min, $90-100 \%$ linear B $82-85 \mathrm{~min}, 100 \%$ B isocratic $85-90$ minutes, followed by washing (methanol/water, 50:50 $\mathrm{v} / \mathrm{v})$ 91-100 $\mathrm{min}$, and rebalancing the column from 101 to $120 \mathrm{~min}$ under initial conditions of the gradient. Detection was performed at $280 \mathrm{~nm}$.

The following flavanol molecules have been quantified: (+)-catechin; (-)-epicatechin; (-)epicatechin 3-O-gallate; procyanidin dimers B1 [(-)epicatechin- $(4 \beta \rightarrow 8)-(+)$-catechin $], \quad$ B2 $\quad[(-)-$ epicatechin- $(4 \beta \rightarrow 8)-(-)$-epicatechin $], \quad$ B3 $\quad[(+)-$ catechin- $(4 \alpha \rightarrow 8)-(+)$-catechin $], \quad$ B4 $\quad[(+)$-catechin$(4 \alpha \rightarrow 8)-(-)$-epicatechin], B1-3-O-gallate [(-)epicatechin-3-O-gallate- $(4 \beta \rightarrow 8)-(+)$-catechin], B2-3$O$-gallate [(-)-epicatechin $(4 \beta \rightarrow 8)-(-)$-epicatechin], B2-3'- $O$-gallate $\quad[(-)$-epicatechin- $(4 \beta \rightarrow 8)-(-)-$ epicatechin-3-O-gallate], trimer $\mathrm{C} 1$ [(-)-epicatechin$(4 \beta \rightarrow 8)-(-)$-epicatechin-( $4 \beta \rightarrow 8)-(-)$-epicatechin $)]$ and trimer $2 \quad(\mathrm{~T} 2) \quad[(-)$-epicatechin- $(4 \beta \rightarrow 8)-(-)-$ epicatechin- $(4 \beta \rightarrow 8)-(+)$-catechin] (Ricardo-da-Silva et al., 1990; Ricardo-da-Silva et al., 1991; Rigaud et al., 1991). The identification of the chemical compounds was done according with studies of Rigaud et al. (1991) and Ricardo-da-Silva et al. (1991) and later confirmed by Monagas et al. (2003). The quantification of monomeric flavan-3-ol and small oligomeric procyanidins (some dimers and trimers) were based on standard curves obtained with $(+)$-catechin and $(-)$-epicatechin $\left(\mathrm{R}^{2}=0.999\right)$ for the monomers and dimer B2 for the other compounds $\left(\mathrm{R}^{2}=0.997\right)$.

Isolation of flavanols in skins and seeds on a fractogel chromatographic column and further degradation by acid catalyzed depolymerization in the presence of toluene- $\alpha$-thiol, following by HPLC analysis

In a glass column of QuickFit CR 12/10 of (100 mm $\mathrm{x} 10 \mathrm{~mm}$ ) filled with fractogel TSK HW-40F (Toyopearl ${ }^{\circledR}$, Japan) $5 \mathrm{~mL}$ of skin or seed extracts has passed with a flow rate of $0.7 \mathrm{~mL} / \mathrm{min}$, maintained by a vacuum pump (Vacuubrand, Germany) model MZ2C.

A mixture of ethanol/water/trifluoroacetic acid (TFA) with concentrations of $(55: 45: 0.05 \mathrm{v} / \mathrm{v} / \mathrm{v})$ was used to conditioned the column before incorporating the 5 $\mathrm{mL}$ extract, the volume of $30 \mathrm{~mL}$ was added. After the passage of the sample, $30 \mathrm{~mL}$ of the solvent containing TFA was added, which allowed the elution of single and monomeric flavonoids (phenolic acids, anthocyanins, flavonols, stilbenes and catechins) and polymeric in increasing order of their degree of polymerization.

The column was washed with $30 \mathrm{~mL}$ of acetone: water $(60: 40 \mathrm{v} / \mathrm{v})$ to collect the polymeric flavonoids that were still attached to the gel. The latter fraction was evaporated to dryness, diluted in $1 \mathrm{~mL}$ of methanol to the seed samples and $0.5 \mathrm{~mL}$ to samples of skins, and then stored at $-20{ }^{\circ} \mathrm{C}$. The preparation of the fractogel column and isolation of flavanols was performed following the method described by Labarbe et al. (1999).

Acid-catalyzed degradation in the presence of toluene- $\alpha$-thiol was performed under the conditions described by Kennedy et al. (2000) and Monagas et al. (2003) but with some modifications. A $100 \mu \mathrm{L}$ portion of the sample was placed in a $1.0 \mathrm{~mL}$ screwcap vial and mixed with $100 \mu \mathrm{L}$ of toluene-R-thiol ( $5 \%$ for seed samples and $12 \%$ for skin) in methanol containing $\mathrm{HCl}(0.2 \mathrm{M})$. The mixture was placed in a $55{ }^{\circ} \mathrm{C}$ water bath for $10 \mathrm{~min}$. The thiolyzed sample was cooled under running water and immediately analyzed by reversed HPLC phase. The equipment used in the analysis was a liquid chromatography with a Merck Hitachi L-7100 pump and Waters 2487 detector. Separation was performed on a reversedphase Gemini C18 110A (150 mm x $3 \mathrm{~mm}$ x $5 \mu \mathrm{m})$ at room temperature. A binary gradient consisting of solvent A (water/formic acid 98:2 v/v) and solvent B (acetonitrile/water/formic acid, 80:18:2 v/v/v) was applied at a flow rate of $1.0 \mathrm{~mL} / \mathrm{min}$ as follows: 0 to 
15 minutes with $10 \%$ solution A e $90 \%$ solution B, followed by washing (solvent B) and reequilibration of the column. The detection was performed at 280 nm.

The calculation of the mean degree of polymerization $(\mathrm{mDP})$, percentage of galloylation (\%g) and percentage of prodelphinidins ( $\% p)$, was based on the peak areas $(\mathrm{kW})$ of the terminal units and extensions after HPLC analysis. The identification of the peaks was based on the work performed by Monagas et al. (2003).

Separation of proanthocyanidins in Sep-Pak C18 cartridges and quantification of the obtained fractions by the vanillin assay

In this method, extracts of skins, pulps, seeds and wine samples were used. The separation of flavanols was performed using a Sep-Pak C18 cartridge (Waters, USA) according to their degree of polymerization in three fractions: monomeric (using ethyl ether as solvent), oligomeric (extracted with methanol) and polymeric fractions (extracted with methanol), following the method described by Sun et al. (1998a).

The flavanol content of each fraction was determined using the vanillin assay according to the method described by Sun et al. (1998b). The quantification was performed by means of standard curves prepared from flavanol monomers, oligomers and polymers of grape seed isolates as described by Sun et al. (1998a,b) and Sun et al. (2001). Extractions on the C18 cartridge and the further measurements after reaction with vanillin were performed in triplicate.

\section{Characterization of the sensory profile of wines}

The sensory evaluation was conducted by a panel of twelve experienced tasters, in Instituto Superior de Agronomia - Lisbon University, Portugal. The panel consisted of seven men and five women with age between twenty-five and forty-five years old. The evaluation of the visual, olfactory and taste characteristics of the wines were carried out with Quantitative Descriptive Analysis (QDA), with 16 attributes: 4 visual sensations (color, color intensity, limpidity and fluidity), five aromatic attributes (fruity, floral, herbaceous, spices and empireumatic) and seven taste attributes (sweetness, acidity, alcohol, bitterness, astringency, body and persistence). The quantification was made by a scale with an unstructured intensity of 10 points, with minimum anchorage on the left and maximum on the right.

Each taster evaluated between one or two samples per session, with three sections: one sample in the first semester of 2015 (wines from 2014 harvest), another in the second semester of 2016 (wines from 2016 harvest - two samples) and in the second semester of 2017 (wines from the first 2017 harvest - one sample). The test room was composed by individual, white and illuminated booths. The samples were served individually, coded in tasting glasses (ISO), each containing $50 \mathrm{~mL}$ of wine, with a temperature of $18 \pm 2{ }^{\circ} \mathrm{C}$, range considered ideal for red wines tasting.

\section{Statistical analysis}

All the chemical analyses performed in this study were made in triplicate and sensory analysis was made by a panel composed by twelve tasters. To verify the differences between the samples, based on four harvest seasons, an analysis of variance (Oneway ANOVA) has been performed. To test the differences between each level of treatment, a multiple mean comparison test (HSD Tukey) has been done. The confidence level utilized in the statistical analysis was $95 \%$, which means max admissible for error type I was $5 \%$. Both analyzes were performed using STATISTIX 9.0 software (Florida, USA).

\section{RESULTS AND DISCUSSION}

\section{Grapes - Chemical composition}

\section{Classic analysis and organic acids in grapes}

The results of classic parameters and organic acids are presented in Table I. It is possible to observe that there was significant effect of the harvest season for $\mathrm{pH}$ and ${ }^{\circ} \mathrm{Brix}$. $\mathrm{pH}$ varied from 3.7 to 3.8 and from 3.8 to 4.0 in the grapes harvested in the first and second semester, respectively. It is possible to verify high $\mathrm{pH}$ values in 'Touriga Nacional' grapes on both harvest seasons, a fact that may be related to the high potassium content found in soils in this region (Soares and Leão, 2009), which reflect the formation of acid salts at the expense of free acids.

In the same Table is possible to detect that was an influence of the harvest season on total acidity, for grapes harvested in the first semester of the year. These contained higher concentrations of tartaric acid: $5.3 \mathrm{~g} / \mathrm{L}$ on I harvest - year 2016 and $6.7 \mathrm{~g} / \mathrm{L}$ on I harvest - year 2017. The high concentrations of total acidity in the harvests may be due to a characteristic of the cultivar, according to Böhm (2007) and Brites and Pedroso (2000). They have reported that the 'Touriga Nacional' variety has high total acidity, with values ranging from $4.5-6.0 \mathrm{~g} / \mathrm{L}$ of tartaric acid, 
based on studies of traditional regions. Another factor that may influence higher total acidity during the first harvest season is the lower degradation of organic acids in this period, due to lower diurnal temperatures and higher thermal amplitude when compared to the second harvest season (Figure 1).

Organic acids were also influenced by the harvest season, with the highest concentrations in grapes harvested in the first semester of the year. The highest content of tartaric acid was $4.6 \mathrm{~g} / \mathrm{kg}$ (I harvest in 2017) and malic acid $3.2 \mathrm{~g} / \mathrm{kg}$ (I harvest in 2017). In a review on biochemistry of organic acids found in grapes, Ford (2012) has reported that tartaric acid was not affected by temperature, but malic acid has the opposite behavior.

\section{TABLE I}

Classical parameters, organic acids, color, global phenolic compounds and monomeric anthocyanins in 'Touriga Nacional' grapes, cultivated in tropical semi-arid region, in Brazilian Northeast

Parâmetros clássicos, ácidos orgânicos, cor, compostos fenólicos globais e antocianinas monoméricas em uvas 'Touriga Nacional', cultivadas em região tropical semiárida, no Nordeste brasileiro

\begin{tabular}{|c|c|c|c|c|c|}
\hline \multirow{2}{*}{ Harvest season } & \multicolumn{2}{|c|}{$1^{\text {st }}$ Year-Experiment essays } & \multicolumn{2}{|c|}{$2^{\text {nd }}$ Year-Experiment essays } & \multirow{2}{*}{$\begin{array}{l}\text { ANOVA } \\
\text { (p-values) }\end{array}$} \\
\hline & I Harvest & II Harvest & I Harvest & II Harvest & \\
\hline \multicolumn{6}{|l|}{ Classic analysis } \\
\hline $\mathrm{pH}$ & $3.81^{\mathrm{ab}} \pm 0.00$ & $4.04^{\mathrm{a}} \pm 0.08$ & $3.75^{\mathrm{b}} \pm 0.00$ & $3.81^{\mathrm{ab}} \pm 0.00$ & $* *$ \\
\hline Total acidity (g/L) & $5.3^{\mathrm{b}} \pm 0.0$ & $4.0^{\mathrm{c}} \pm 0.1$ & $6.7^{\mathrm{a}} \pm 0.0$ & $4.9^{\mathrm{b}} \pm 0.1$ & $* * *$ \\
\hline SST $\left({ }^{\circ}\right.$ Brix $)$ & $19.7^{\mathfrak{c}} \pm 0.1$ & $21.2^{\mathrm{ab}} \pm 0.1$ & $22.0^{\mathrm{a}} \pm 0.1$ & $20.6^{\mathrm{b}} \pm 0.0$ & $* *$ \\
\hline \multicolumn{6}{|l|}{ Organic acids (g/kg) } \\
\hline Tartaric acid & $3.1^{\mathrm{c}} \pm 0.0$ & $2.4^{\mathrm{d}} \pm 0.1$ & $4.6^{\mathrm{a}} \pm 0.1$ & $3.8^{\mathrm{b}} \pm 0.1$ & $* * *$ \\
\hline Malic acid & $2.4^{\mathrm{b}} \pm 0.0$ & $1.5^{\mathrm{c}} \pm 0.0$ & $3.2^{\mathrm{a}} \pm 0.2$ & $3.0^{\mathrm{a}} \pm 0.2$ & $* *$ \\
\hline \multicolumn{6}{|l|}{ Color and phenolic compounds } \\
\hline Total phenols (mg/kg) & $600.7^{\mathrm{d}} \pm 4.0$ & $713.6^{c} \pm 3.9$ & $932.7^{\mathrm{a}} \pm 2.2$ & $734.5^{b} \pm 6.9$ & $* * *$ \\
\hline Flavonoids (mg/kg) & $322.1^{\mathrm{d}} \pm 5.5$ & $600.9^{\mathrm{b}} \pm 5.7$ & $751.9^{\mathrm{a}} \pm 2.8$ & $416.4^{\mathrm{c}} \pm 3.1$ & $* * *$ \\
\hline Non-flavonoids (mg/kg) & $169.9^{\mathrm{b}} \pm 0.9$ & $113.4^{\mathrm{c}} \pm 2.1$ & $181.2^{\mathrm{a}} \pm 0.7$ & $111.3^{\mathrm{c}} \pm 0.1$ & $* * *$ \\
\hline Total anthocyanins $(\mathrm{mg} / \mathrm{kg})$ & $426.8^{\mathrm{b}} \pm 4.0$ & $462.1^{\mathrm{a}} \pm 13.6$ & $416.9^{\mathrm{b}} \pm 0.9$ & $353.0^{\mathrm{c}} \pm 2.1$ & $* *$ \\
\hline Color Intensity (u.a) & $6.723^{\mathrm{c}} \pm 0.034$ & $10.347^{\mathrm{b}} \pm 0.045$ & $16.163^{\mathrm{a}} \pm 0.101$ & $6.377^{\mathrm{c}} \pm 0.025$ & $* *$ \\
\hline Tonality (u.a) & $0.629^{\mathrm{a}} \pm 0.005$ & $0.604^{\mathrm{a}} \pm 0.001$ & $0.494^{\mathrm{c}} \pm 0.002$ & $0.576^{\mathrm{b}} \pm 0.008$ & $*$ \\
\hline \multicolumn{6}{|l|}{ Monomeric anthocyanins (mg/g) } \\
\hline \multicolumn{6}{|l|}{ Non-acylated } \\
\hline Delphinidin 3-O-glucoside & $23.0^{\mathrm{a}} \pm 0.5$ & $15.1^{\mathrm{b}} \pm 0.6$ & $15.6^{\mathrm{b}} \pm 1.5$ & $6.0^{\mathrm{c}} \pm 0.3$ & $* *$ \\
\hline Cyanidin 3-O-glucoside & $4.1^{\mathrm{b}} \pm 0.3$ & $2.4^{\mathrm{c}} \pm 0.2$ & $5.2^{\mathrm{a}} \pm 0.1$ & $1.3^{\mathrm{d}} \pm 0.1$ & $* *$ \\
\hline Peonidin 3-O-glucoside & $15.3^{\mathrm{d}} \pm 0.5$ & $22.5^{\mathrm{b}} \pm 2.3$ & $25.0^{\mathrm{a}} \pm 0.5$ & $18.9^{\mathrm{c}} \pm 0.9$ & $*$ \\
\hline Petunidin 3-O-glucoside & $20.7^{\mathrm{a}} \pm 0.3$ & $8.1^{\mathrm{c}} \pm 0.5$ & $18.8^{\mathrm{b}} \pm 0.5$ & $4.1^{\mathrm{d}} \pm 0.0$ & $* *$ \\
\hline Malvidin 3-O-glucoside & $40.1^{\mathrm{c}} \pm 0.4$ & $61.9^{\mathrm{b}} \pm 5.0$ & $77.6^{\mathrm{a}} \pm 2.5$ & $62.3^{\mathrm{b}} \pm 1.3$ & $* *$ \\
\hline \multicolumn{6}{|l|}{ Acetylated (mg/g) } \\
\hline Peonidin 3-O-acetylglucoside & $0.8^{\mathrm{ab}} \pm 0.0$ & $0.1^{\mathrm{d}} \pm 0.0$ & $1.0^{\mathrm{a}} \pm 0.1$ & $0.4^{\mathrm{c}} \pm 0.0$ & $* *$ \\
\hline Petunidin 3-O-acetylglucoside & $4.6^{\mathrm{b}} \pm 0.1$ & $0.0^{\mathrm{d}} \pm 0.0$ & $9.2^{\mathrm{a}} \pm 0.7$ & $0.8^{\mathrm{c}} \pm 0.0$ & $* *$ \\
\hline Cyanidin 3-O-acetylglucoside & $0.3^{\mathrm{c}} \pm 0.0$ & $2.2^{\mathrm{a}} \pm 0.4$ & $0.4^{\mathrm{c}} \pm 0.1$ & $0.9^{\mathrm{b}} \pm 0.0$ & $*$ \\
\hline Delphinidin 3-O-acetylglucoside & $2.9^{\mathrm{b}} \pm 0.1$ & $0.0^{\mathrm{d}} \pm 0.0$ & $6.1^{\mathrm{a}} \pm 0.2$ & $0.5^{\mathrm{b}} \pm 0.0$ & $* * *$ \\
\hline Malvidin 3-O-acetylglucoside & $12.2^{\mathrm{c}} \pm 0.1$ & $13.7^{\mathrm{b}} \pm 1.0$ & $6.9^{\mathrm{d}} \pm 0.2$ & $14.7^{\mathrm{a}} \pm 0.4$ & * \\
\hline \multicolumn{6}{|l|}{ Coumaroylated (mg/g) } \\
\hline Peonidin 3-O-coumarylglucoside & $0.7^{\mathrm{b}} \pm 0.0$ & $1.9^{\mathrm{a}} \pm 0.1$ & $0.0^{\mathrm{c}} \pm 0.0$ & $0.8^{\mathrm{b}} \pm 0.0$ & $* * *$ \\
\hline Petunidin 3-O-coumarylglucoside & $0.5^{\mathrm{c}} \pm 0.0$ & $0.8^{\mathrm{b}} \pm 0.0$ & $1.1^{\mathrm{a}} \pm 0.1$ & $0.3^{\mathrm{c}} \pm 0.0$ & $* *$ \\
\hline Delphinidin 3-O-coumarylglucoside & $8.1^{\mathrm{b}} \pm 0.5$ & $8.9^{\mathrm{b}} \pm 0.4$ & $15.5^{\mathrm{a}} \pm 0.6$ & $5.4^{\mathrm{c}} \pm 0.1$ & $* *$ \\
\hline Malvidin 3-O-coumarylglucoside & $5.9^{\mathrm{b}} \pm 0.1$ & $5.1^{\mathrm{c}} \pm 0.2$ & $7.5^{\mathrm{a}} \pm 0.3$ & $5.8^{\mathrm{b}} \pm 0.1$ & $*$ \\
\hline \multicolumn{6}{|l|}{ Total monomeric anthocyanins $(\mathrm{mg} / \mathrm{g})$} \\
\hline & $139.2^{\mathrm{bc}} \pm 1.0$ & $142.7^{\mathrm{b}} \pm 8.3$ & $189.9^{\mathrm{a}} \pm 6.1$ & $122.2^{\mathrm{d}} \pm 2.8$ & $*$ \\
\hline
\end{tabular}

Means within the same row followed by different letters are significantly different according to the Tukey test ( $<<0.05$ ); $*$ significant differences at $95 \%$ confidence level; $* *$ significant differences at $99.9 \%$ confidence level; $* * *$ significant differences at 99.99\% confidence level; I Harvest - first semester, years 2016 and 2017; II Harvest - second semester, years 2014 and 2016 ; Total acidity (g/L of tartaric acid); SST - total soluble solids; u.a. - absorbance units. 
The low malic acid content in the second harvest semester can be related to degradation due to high minimal and average temperatures during this period in the region (Figure 1). According to some authors, warm-weather grapes tend to have a faster respiration rate with L-malic acid compared to cold regions, thus having a reduced concentration of this acid (Volschenkla et al., 2006).

\section{Phenolic compounds and color in grapes}

Concentrations of total flavonoid and non-flavonoid phenols are shown in Table I. The contents varied between years and not in the harvest season for total flavonoid phenols. The concentration of nonflavonoids remained higher in the first harvest semester, following the pattern of other organic acids present in grapes. The highest concentrations obtained in this study were the following: total phenols $932.7 \mathrm{mg} / \mathrm{kg}$, flavonoids $751.9 \mathrm{mg} / \mathrm{kg}$, and nonflavonoids $181.2 \mathrm{mg} / \mathrm{kg}$.

The concentration of total anthocyanins in the grapes was influenced by the harvest season and between the years of study (Table I). The highest concentration was $462.1 \mathrm{mg} / \mathrm{kg}$ of malvidin in 2014 and was found on the harvest of the second semester, followed by $426.8 \mathrm{mg} / \mathrm{kg}$ of malvidin in the first harvest season of 2016. As reported by some authors, the accumulation of anthocyanins in the berries is influenced by temperature; the ideal range would be between 17-18 ${ }^{\circ} \mathrm{C}$ (night) and $24-26{ }^{\circ} \mathrm{C}$ during the day (Yamane and Shibayama, 2006). Temperatures above $35{ }^{\circ} \mathrm{C}$ promote the anthocyanins degradation (Kliewer and Torres, 1972; Reynolds, 2010). Thus, higher concentrations of anthocyanins were expected for the grapes of the first harvest season than for those of the second, due to lower temperatures, but the high concentration in one of the harvests of the second semester may be related to a characteristic of the variety that promotes lesser degradation of anthocyanins during maturation. Further studies are needed to confirm this aspect. Jordão et al. (1998) showed that anthocyanins increase gradually during maturation of 'Castelão' variety under traditional viticulture conditions.

\section{Monomeric anthocyanins in grapes}

Fourteen monomeric anthocyanins (Table I) were identified and quantified, and most of them were influenced by the harvest season. Regarding the five non-acylated anthocyanins, three remained in high concentrations for grapes harvested in the first semester, in time period of this study. Those are: delphinidin, cyanidin and petunidin. The highest amounts for these anthocyanins were $23.0 \mathrm{mg} / \mathrm{g}, 5.2$ $\mathrm{mg} / \mathrm{g}$ and $20.7 \mathrm{mg} / \mathrm{g}$, respectively. For peonidin and malvidin, there was no trend for a particular harvest season; concentrations varied between the years of this study. The highest amounts were $25 \mathrm{mg} / \mathrm{g}$ and $77.6 \mathrm{mg} / \mathrm{g}$ for peonidin and malvidin, respectively, all in the 2017 first harvest. Table I also present nonacylated anthocyanins that are pigments with the highest concentrations within the group of monomeric anthocyanins, which was also reported in other studies (Roggero et al., 1986; Jordão et al., 1998; Mulinacci et al., 2008; Jordão and Correia, 2012). The highest concentrations of non-acylated anthocyanins may be related to lower degradation due to less minimum and average temperatures in first semester compared with semester.

In relation to acetylated anthocyanins (Table I) results indicate that there was an influence of the harvest season on the profile of these anthocyanins, except for peonidin. Anthocyanin petunidin 3-Oacetylglucoside and delphinidin 3-O-acetylglucoside were higher in the first harvest season of the year, with $9.2 \mathrm{mg} / \mathrm{g}$ and $6.1 \mathrm{mg} / \mathrm{g}$, respectively. The cyanidin 3-O-acetylglucoside and malvidin 3-Oacetylglucoside had higher concentrations in the second harvest season with $2.2 \mathrm{mg} / \mathrm{g}$ and $14.7 \mathrm{mg} / \mathrm{g}$, respectively. The concentrations of anthocyanins esterified with acetic acid from the semi-arid region of Brazil were higher than that reported by Mateus et al. (2001) when evaluating the skins of 'Touriga Nacional' grapes in Douro region, in Portugal (300$350 \mathrm{~m}$ altitude), in which they have quantified values below $1 \mathrm{mg} / \mathrm{g}$ in berries.

Concentrations of coumaroylated anthocyanins are also shown in Table I. For four anthocyanins analysed in this study, it has been detected statistical differences for the harvesting effect. The highest concentrations on the first harvest season were obtained for petunidin 3-O-coumarylglucoside (1.1 $\mathrm{mg} / \mathrm{g}$ ), delphinidin 3-O-coumarylglucoside (15.5 $\mathrm{mg} / \mathrm{g}$ ) and malvidin 3-O-coumarylglucoside (5.9 $\mathrm{mg} / \mathrm{g}$ ). On the second harvest season, the highest concentration was reached for anthocyanin peonidin 3-O-coumarylglucoside with $1.9 \mathrm{mg} / \mathrm{g}$.

Concerning the total concentration of monomeric anthocyanins, no tendency for higher concentrations in a specific harvest season has been detected. The highest content of total monomeric anthocyanins was $189.9 \mathrm{mg} / \mathrm{g}$ for grapes harvested in 2017 first harvest season, followed by $142.7 \mathrm{mg} / \mathrm{g}$ in 2014 second harvest season.

\section{Condensed tannins in seeds, skins and pulps}

The concentrations of monomeric, oligomeric and polymeric tannins in the seeds are presented in Table II. 


\section{TABLE II}

Condensed tannins in seeds, skins and pulps of 'Touriga Nacional' variety, cultivated in semi-arid tropical region of Brazil, during four harvest seasons

Taninos condensados em grainhas, películas e polpas da variedade 'Touriga Nacional', cultivada em região tropical semiárida do Brasil, durante quatro épocas de colheita

\begin{tabular}{|c|c|c|c|c|c|}
\hline \multirow{2}{*}{ Harvest season } & \multicolumn{2}{|c|}{$1^{\text {st }}$ Year-Experiment essays } & \multicolumn{2}{|c|}{$2^{\text {nd }}$ Year-Experiment essays } & \multirow{2}{*}{$\begin{array}{l}\text { ANOVA } \\
\text { (p-values) }\end{array}$} \\
\hline & I Harvest & II Harvest & I Harvest & II Harvest & \\
\hline \multicolumn{6}{|l|}{ Condensed tannins in seeds $(\mathrm{mg} / \mathrm{g})$} \\
\hline Monomeric & $0.5^{\mathrm{b}} \pm 0.0$ & $1.0^{\mathrm{a}} \pm 0.1$ & $1.1^{\mathrm{a}} \pm 0.0$ & $0.5^{\mathrm{b}} \pm 0.1$ & $* * *$ \\
\hline Oligomeric & $3.5^{\mathrm{c}} \pm 0.1$ & $4.2^{\mathrm{b}} \pm 0.1$ & $5.2^{\mathrm{a}} \pm 0.0$ & $3.3^{\mathrm{c}} \pm 0.0$ & $* *$ \\
\hline Polymeric & $22.4^{\mathrm{b}} \pm 0.5$ & $20.9^{\mathrm{c}} \pm 0.5$ & $23.5^{\mathrm{a}} \pm 0.0$ & $21.8^{\mathrm{b}} \pm 0.0$ & * \\
\hline Total tannins in seeds & $26.4^{\mathrm{b}} \pm 0.5$ & $26.1^{\mathrm{b}} \pm 0.0$ & $30.1^{\mathrm{a}} \pm 0.6$ & $25.6^{\mathrm{c}} \pm 0.0$ & $*$ \\
\hline Mean degree of polimerization (mDP) & $8.7^{\mathrm{d}} \pm 0.1$ & $9.1^{\mathrm{c}} \pm 0.6$ & $12.6^{\mathrm{b}} \pm 0.4$ & $16.3^{\mathrm{a}} \pm 0.3$ & $* *$ \\
\hline$(\%)$ galloylation & $36.2^{\mathrm{b}} \pm 0.1$ & $28.3^{\mathrm{d}} \pm 0.6$ & $30.5^{\mathrm{c}} \pm 0.0$ & $40.1^{\mathrm{a}} \pm 0.0$ & $* *$ \\
\hline \multicolumn{6}{|l|}{ Condensed tannins in skins (mg/g) } \\
\hline Monomeric & $0.1^{\mathrm{ab}} \pm 0.0$ & $0.2^{\mathrm{ab}} \pm 0.1$ & $0.1^{\mathrm{ab}} \pm 0.0$ & $0.1^{\mathrm{ab}} \pm 0.0$ & n.s. \\
\hline Oligomeric & $1.9^{\mathrm{a}} \pm 0.3$ & $2.1^{\mathrm{a}} \pm 0.5$ & $1.3^{\mathrm{b}} \pm 0.0$ & $1.9^{\mathrm{a}} \pm 0.5$ & $* *$ \\
\hline Polymeric & $3.3^{\mathrm{a}} \pm 0.1$ & $2.9^{\mathrm{b}} \pm 0.7$ & $3.2^{\mathrm{a}} \pm 0.1$ & $3.3^{\mathrm{a}} \pm 0.3$ & $*$ \\
\hline Total tannins in skins & $5.3^{\mathrm{a}} \pm 0.4$ & $5.2^{\mathrm{a}} \pm 0.2$ & $4.6^{\mathrm{b}} \pm 0.1$ & $5.3^{\mathrm{a}} \pm 0.1$ & $*$ \\
\hline Mean degree of polimerization (mDP) & $23.3^{\mathrm{c}} \pm 0.0$ & $28.8^{\mathrm{b}} \pm 0.4$ & $22.1^{\mathrm{d}} \pm 0.0$ & $31.4^{\mathrm{a}} \pm 0.8$ & $*$ \\
\hline$(\%)$ galloylation & $7.2^{\mathrm{a}} \pm 0.2$ & $3.1^{\mathrm{c}} \pm 0.0$ & $3.0^{\mathrm{c}} \pm 0.0$ & $4.2^{\mathrm{b}} \pm 0.5$ & $* *$ \\
\hline$(\%)$ prodelphinidins & $9.4^{\mathrm{a}} \pm 0.1$ & $6.1^{\mathrm{c}} \pm 0.2$ & $8.5^{\mathrm{b}} \pm 0.1$ & $8.1^{\mathrm{b}} \pm 0.0$ & $* *$ \\
\hline \multicolumn{6}{|l|}{ Condensed tannins in pulp (mg/g) } \\
\hline Monomeric & $0.02^{\mathrm{ab}} \pm 0.02$ & $0.02^{\mathrm{ab}} \pm 0.00$ & $0.01^{\mathrm{ab}} \pm 0.00$ & $0.02^{\mathrm{ab}} \pm 0.00$ & n.s. \\
\hline Oligomeric & $0.05^{\mathrm{b}} \pm 0.00$ & $0.07^{\mathrm{ab}} \pm 0.00$ & $0.09^{\mathrm{a}} \pm 0.00$ & $0.05^{\mathrm{b}} \pm 0.00$ & $*$ \\
\hline Polymeric & $0.11^{\mathrm{b}} \pm 0.00$ & $0.11^{\mathrm{b}} \pm 0.00$ & $0.27^{\mathrm{a}} \pm 0.21$ & $0.13^{\mathrm{b}} \pm 0.03$ & $*$ \\
\hline Total tannins in pulps & $0.10^{\mathrm{bc}} \pm 0.00$ & $0.20^{\mathrm{bc}} \pm 0.03$ & $0.37^{\mathrm{a}} \pm 0.12$ & $0.20^{\mathrm{bc}} \pm 0.11$ & $*$ \\
\hline
\end{tabular}

For monomeric and oligomeric tannins, a greater effect due to the year of study rather than the harvest season seems to exist, with highest concentrations for these compounds of 1.1 and $5.2 \mathrm{mg} / \mathrm{g}$, respectively. As for polymeric tannins in seeds, it has been detected an effect of the harvest season, with the highest content in grapes harvested in the first season, with values of 22.4 up to $23.5 \mathrm{mg} / \mathrm{g}$, for the two years of study, respectively. The values of polymeric tannins in the seeds used for this study were slightly below from those reported by Cosme et al. (2009) for the same cultivar, in Lisbon region, where they have quantified $27.1 \mathrm{mg} / \mathrm{g}$ at harvest time.

The mean degree of polymerization $(\mathrm{mDP})$ in seeds varied on first harvest season from 8.7 up to 12.6 and in the second harvest season from 9.1 up to 16.3 , respectively, demonstrating that there was an effect of the harvest season, with higher values in the grapes harvested in the second semester of the year. This fact can be related to a greater presence of polymerized tannins due to a divergence between the technological and phenolic maturation of the grapes in this region, where during the harvest of the berries is still present green tannins. This may be related to the high temperatures in the second season that lead to a faster ripening of the grapes. According to some authors (Kennedy et al., 2000; Bordiga et al., 2011) in studies in regions with traditional production it has been detected that $\mathrm{mDP}$ generally decreases during maturation. These values are higher than those reported by Cosme et al. (2009) for 'Touriga Nacional' grape seed extract, under traditional viticulture conditions, in which $\mathrm{mDP}$ of 6.2 was observed for the mentioned grape variety. The values 
obtained for $\mathrm{mDP}$ were also higher than those cited by Obreque-Slier et al. (2010) for seeds from other red varieties, where it has been quantified a $\mathrm{mDP}$ of 3.2 for 'Carmenére' and $\mathrm{mDP}$ of 2.7 for 'Cabernet Sauvignon', in Maule Valley in Chile region. However, Sun et al. (1998a) found $\mathrm{mDP}$ values of 31.5 in the polymeric fraction of grape seeds ('Tinta Miúda' variety), in Portugal, the highest values encountered. The mDP values of this study are also in agreement with the values cited by Spranger et al. (2009) in cv. 'Fernão Pires', where it was detected values of $\mathrm{mDP}$ varying from 0.02 up to 17.8 in the oligomeric fraction and $\mathrm{mDP}$ ranging from 0.01 up to 34.5 in the polymeric fraction of the seeds.

The percentage of galloylation was not influenced by the harvest season, but varied between the years of study, with the highest percentage of 40.1 in grape seeds harvested in the second semester of 2016. The percentage of galloylation was higher in this study than those mentioned by Monagas et al. (2003) for seeds of the 'Graciano' (10.9\%), 'Tempranillo' (14.3\%) and 'Cabernet Sauvignon' (12.9\%); by Obreque-Slier et al. (2010) for seeds of other red varieties, it was quantified $27.5 \%$ for 'Carmenére' and $16.3 \%$ for 'Cabernet Sauvignon'. Other authors, such as Cosme et al. (2009), evaluating the seeds of the varieties' Vitis vinifera L. 'Touriga Nacional' (16.4\%), 'Trincadeira' (18.5\%), 'Cabernet Sauvignon' (19.7\%), 'Castelão' (18.6\%) and 'Syrah' (18.7\%), being the studies reported by the previous authors made in traditional wine-growing regions.

The condensed tannins of the skins are presented in Table II. It is possible to observe that there was an influence of the harvest season. The monomeric flavan-3-ols varied from 0.1 up to $0.2 \mathrm{mg} / \mathrm{g}$, the oligomeric tannins ranged from 1.3 up to $2.1 \mathrm{mg} / \mathrm{g}$ and the polymer tannins ranged from 2.9 up to 3.3 $\mathrm{mg} / \mathrm{g}$, respectively. Concentration of total tannins was not influenced by the time of harvest and the results of the study ranged from $4.6 \mathrm{mg} / \mathrm{g}$ up to $5.3 \mathrm{mg} / \mathrm{g}$. These values are higher than those reported by Cosme et al. (2009) for the same variety, in the region of Lisbon - Portugal, in which were quantified concentrations of $0.02 \mathrm{mg} / \mathrm{g}$ for monomeric tannins, $0.01 \mathrm{mg} / \mathrm{g}$ for oligomeric tannins and $2.36 \mathrm{mg} / \mathrm{g}$ for polymer tannins.

The mean degree of polymerization in the skins was higher in grapes harvested in the second harvest season of the year, being the highest value 31.4 , as it was found for grape seeds. This fact can be related to a faster ripening in grapes from second harvest season, which occurs mainly due to the high temperatures during the production cycle (Figure 1) as may be observed during the study of the grapes from the second semester containing lower total acidity (Table I) and greater mDP in skins (Table II). According to Kennedy et al. (2001) and ObrequeSlier et al. (2010) on the grape skins, mDP increases during maturation.

The percentage of galloylation in the skins was affected by the harvest season and the values varied from $3.0 \%$ up to $7.2 \%$ in the harvest of the first semester and $3.1 \%$ to $4.2 \%$ in the second harvest season, respectively. The proportion of prodelphinidins was higher in skins of grapes harvested in the first harvest season, being $9.4 \%$ the higher result. The values of $\mathrm{mDP}$ and percentage prodelphinidins $(\% \mathrm{p})$ for 'Touriga Nacional' grape skins, under semi-arid conditions were lower than those reported in the literature for other red varieties, such as 'Tempranillo' skins ( $\mathrm{mDP} 72.3$ and \%p 13.3), 'Graciano' (mDP 33.8 and \%p 10.7). Monagas et al. (2003) and Bordiga et al. (2011) have analysed 'Cabernet Sauvignon' skins and they found values of mDP 36.6 and $53.9 \%$ of prodelphinidins.

In this study, small amounts of condensed tannins were detected in the pulp of the grape samples. According to Sun et al. (2001) the proanthocyanidins present in the pulp may result in some kind of contamination during the pulp separation from the skins that was made for the preparation of the extracts.

\section{Monomeric and small oligomeric flavanols in seeds}

The concentration of the flavanol phenolic compounds from grape seeds is shown in Table III. It is observed that the monomeric flavanols catechin and epicatechin were influenced by the harvest season, with higher concentrations in the first harvest season of the year. The quantities detected on seeds were $1038.1 \mathrm{mg} / \mathrm{kg}$ of seeds and $701.5 \mathrm{mg} / \mathrm{kg}$ of seeds, for catechin and epicatechin, respectively. Data indicate no significant effect of the harvest time on the concentration of epicatechin 3-O-gallate, but an influence of the year. Their concentration ranged from 6.4 up to $14.8 \mathrm{mg} / \mathrm{kg}$ of seeds in the first harvest season and from $5.4 \mathrm{p}$ to $15.3 \mathrm{mg} / \mathrm{kg}$ of seeds in the second harvest season, respectively.

For the flavanol dimers extracted from seeds, it was observed that they were influenced by the harvesting season. The concentrations of dimer B1 varied from 5.7 to $11.5 \mathrm{mg} / \mathrm{kg}$, the dimer B2 varied from 219 to $429.8 \mathrm{mg} / \mathrm{kg}$, B3 ranged from 5.7 to $64.6 \mathrm{mg} / \mathrm{kg}$, and B4 ranged from 6.5 up to $19.7 \mathrm{mg} / \mathrm{kg}$. 
TABLE III

Monomeric flavanols and procyanidins in seeds of 'Touriga Nacional', cultivated in semi-arid tropical region of Brazil, during four harvest seasons

Flavanóis monoméricos e procianidinas em grainhas de 'Touriga Nacional', cultivadas em região tropical semiárida do Brasil, durante quatro épocas de colheita

\begin{tabular}{|c|c|c|c|c|c|}
\hline \multirow{2}{*}{ Harvest season } & \multicolumn{2}{|c|}{$1^{\text {st }}$ Year-Experiment essays } & \multicolumn{2}{|c|}{$2^{\text {nd }}$ Year-Experiment essays } & \multirow{2}{*}{$\begin{array}{l}\text { ANOVA } \\
\text { (p-values) }\end{array}$} \\
\hline & I Harvest & II Harvest & I Harvest & II Harvest & \\
\hline \multicolumn{6}{|c|}{ Monomeric flavanols (mg/kg) } \\
\hline$(+)$ catechin & $1000.6^{\mathbf{b}} \pm 0.1$ & $397.9^{d} \pm 6.3$ & $1038.1^{\mathrm{a}} \pm 0.1$ & $520.8^{\mathbf{c}} \pm 0.9$ & $*$ \\
\hline (-) epicatechin & $615.7^{\mathbf{b}} \pm 0.6$ & $429.6^{\mathrm{d}} \pm 4.1$ & $701.5^{\mathrm{a}} \pm 0.9$ & $506.1^{\mathrm{c}} \pm 1.9$ & $* *$ \\
\hline (-) epicatechin 3-O-gallate & $6.4^{\mathbf{b}} \pm 0.0$ & $15.3^{\mathrm{a}} \pm 0.3$ & $14.8^{\mathbf{a}} \pm 0.4$ & $5.4^{\mathrm{c}} \pm 0.0$ & $* *$ \\
\hline \multicolumn{6}{|l|}{ Procyanidin dimers (mg/kg) } \\
\hline B1 & $11.5^{\mathbf{c}} \pm 0.1$ & $71.4^{\mathrm{a}} \pm 6.0$ & $5.7^{\mathrm{d}} \pm 0.9$ & $50.8^{\mathbf{b}} \pm 0.1$ & $*$ \\
\hline $\mathrm{B} 2$ & $219.0^{\mathrm{d}} \pm 0.1$ & $293.3^{\mathbf{b}} \pm 0.6$ & $429.8^{\mathrm{a}} \pm 0.3$ & $280.7^{\mathfrak{c}} \pm 0.9$ & $*$ \\
\hline B3 & $5.7^{\mathrm{d}} \pm 0.0$ & $64.6^{\mathrm{a}} \pm 3.4$ & $15.3^{\mathbf{b}} \pm 0.0$ & $9.8^{\mathbf{c}} \pm 0.0$ & $*$ \\
\hline B4 & $6.5^{\mathrm{d}} \pm 0.0$ & $15.2^{\mathbf{b}} \pm 1.3$ & $19.7^{\mathrm{a}} \pm 0.1$ & $12.7^{\mathbf{c}} \pm 0.7$ & $*$ \\
\hline \multicolumn{6}{|c|}{ Procyanidin dimers gallate (mg/kg) } \\
\hline B1 3-O-gallate & $26.3^{\mathrm{d}} \pm 0.0$ & $82.7^{\mathrm{a}} \pm 0.1$ & $59.5^{\mathrm{b}} \pm 0.0$ & $36.2^{\mathrm{c}} \pm 0.1$ & $* *$ \\
\hline B2 3-O-gallate & $7.1^{\mathrm{c}} \pm 0.0$ & $12.3^{\mathrm{a}} \pm 2.4$ & $9.5^{\mathbf{b}} \pm 0.0$ & $7.2^{\mathfrak{c}} \pm 0.0$ & * \\
\hline B2 3'-O-gallate & $27.1^{\mathbf{b}} \pm 0.0$ & $22.7^{\mathbf{c}} \pm 2.9$ & $40.2^{\mathrm{a}} \pm 0.0$ & $27.2^{\mathbf{b}} \pm 0.0$ & * \\
\hline \multicolumn{6}{|c|}{ Procyanidins trimers (mg/kg) } \\
\hline $\mathrm{C} 1$ & $6.1^{\mathrm{c}} \pm 0.6$ & $15.9^{\mathbf{a}} \pm 0.1$ & $12.6^{\mathbf{b}} \pm 0.1$ & $11.7^{\mathbf{b}} \pm 0.1$ & $*$ \\
\hline Trimer 2 & $3.1^{\mathrm{d}} \pm 0.0$ & $13.5^{\mathrm{a}} \pm 3.7$ & $6.8^{\mathbf{c}} \pm 0.1$ & $9.9^{\mathbf{b}} \pm 0.1$ & $*$ \\
\hline \multicolumn{6}{|l|}{ Total small flavanols ( $\mathrm{mg} / \mathrm{kg})$} \\
\hline & $1935.1^{\mathrm{b}} \pm 16.8$ & $1434.0^{c} \pm 15.3$ & $2353.5^{\mathrm{a}} \pm 19.5$ & $1478.5^{\mathrm{c}} \pm 10.9$ & $* *$ \\
\hline
\end{tabular}

The concentrations of B1 and B4 were lower than those reported in the literature by Ricardo-da-Silva et al. (1992) for seeds belonging to the variety 'Carignan' (B1 - $0.53 \mathrm{mg} / \mathrm{g}$ and B4 $-0.91 \mathrm{mg} / \mathrm{g}$, both extracted from seeds) and 'Mourvèdre' (B1 - 0.73 $\mathrm{mg} / \mathrm{g}$ and B4 - $1.32 \mathrm{mg} / \mathrm{g}$, extracted from seeds) as well as results found by Obreque-Slier et al. (2010) in 'Carmenere' grape seeds (B1 - $37.6 \mathrm{mg} / \mathrm{kg}$ and B4 $37.1 \mathrm{mg} / \mathrm{kg}$ ) and 'Cabernet Sauvignon' (B1 - 29.2 $\mathrm{mg} / \mathrm{kg}$ and B4 - $43.6 \mathrm{mg} / \mathrm{kg}$ ). For procyanidins B2 and B3 the concentrations were higher than those reported by the previous authors.

Concerning the trimer of procyanidins $\mathrm{C} 1$ and $\mathrm{T} 2$ present in seeds (Table III), it was verified that the highest concentrations were in the second harvest season (2014) with $15.9 \mathrm{mg} / \mathrm{kg}$ and $13.5 \mathrm{mg} / \mathrm{kg}$, respectively. There is a tendency for higher concentrations of trimer 2 in the second harvest season.
The concentrations of total small flavanols extracted from seeds were higher in samples from the first harvest season, with values varying from 1935.1 $\mathrm{mg} / \mathrm{kg}$ up to $2353.5 \mathrm{mg} / \mathrm{kg}$.

The high concentrations of catechin and epicatechin also detected in the first harvest may have contributed to this behavior because other compounds had variations between the periods of time of this study, and not between harvest seasons. Some authors have also reported the vintage effect on the composition of flavanols from seed extracts in other grape varieties. Fuleki and Ricardo-da-Silva (1997) have analysed seventeen cultivars in Ontario - Canada, in 1993 and 1994 harvests, Ferrer-Gallego et al. (2012) have studied 'Graciano' variety in Spain, Hernández et al. (2016) have analysed 'Graciano', 'Tempranillo' and their hybrids (grown at Viveros Provedo in La Rioja, Spain between 2008 and 2010, and reached to the same conclusion: the vintage effect in the flavanol seed chemical composition. 


\section{Monomeric and small oligomeric flavanols in skins}

Table IV presents the results of flavanol concentrations in grape skins. Regarding monomeric flavanols, it is possible to detect that concentrations had higher variation in the year of the experiment than between harvest seasons. Catechin, epicatechin and epicatechin 3-O-gallate presented higher concentrations in the skins of the grapes from the second harvest season, in 2016, with results of 72.8 $\mathrm{mg} / \mathrm{kg}, \quad 117.4 \mathrm{mg} / \mathrm{kg}$ and $1.6 \mathrm{mg} / \mathrm{kg}$ of skins, respectively. Among the monomers quantified in grape skins, epicatechin was the major flavanol.
As regards the dimeric procyanidins, it was observed that from the seven compounds analysed from the skins of the grapes that only three were influenced by the harvest season: B1 and B2 (higher concentrations in the first harvest season) and B2 3'-O-gallate (higher concentration on the skins of the grapes from the second harvest season). The other compounds varied between the period of time of this study. The highest concentrations were $14.0 \mathrm{mg} / \mathrm{kg}$ (B1), $74.2 \mathrm{mg} / \mathrm{kg}$ (B2) and $5.2 \mathrm{mg} / \mathrm{kg}$ of skins (B2 3'-O-gallate).

B2 dimer (Table IV) was predominant in the skins of 'Touriga Nacional' grapes in the region of this study.

TABLE IV

Monomeric flavanols and procyanidins obtained from skins of 'Touriga Nacional', cultivated in semi-arid tropical region of Brazil, during four harvest seasons

Flavanóis monoméricos e procianidinas em peliculas de 'Touriga Nacional', cultivadas em região tropical semiárida do Brasil, durante quatro épocas de colheita

\begin{tabular}{|c|c|c|c|c|c|}
\hline \multirow{2}{*}{ Harvest season } & \multicolumn{2}{|c|}{$1^{\text {st }}$ Year-Experiment essays } & \multicolumn{2}{|c|}{$2^{\text {nd }}$ Year-Experiment essays } & \multirow{2}{*}{$\begin{array}{l}\text { ANOVA } \\
\text { (p-values) }\end{array}$} \\
\hline & I Harvest & II Harvest & I Harvest & II Harvest & \\
\hline \multicolumn{6}{|c|}{ Monomeric flavanols (mg/kg) } \\
\hline$(+)$ catechin & $44.1^{\mathrm{b}} \pm 0.3$ & $37.6^{\mathrm{c}} \pm 0.1$ & $38.2^{\mathrm{c}} \pm 0.5$ & $72.8^{\mathrm{a}} \pm 0.0$ & $* *$ \\
\hline (-) epicatechin & $98.2^{\mathrm{b}} \pm 0.0$ & $35.5^{\mathrm{d}} \pm 0.0$ & $89.1^{\mathrm{c}} \pm 0.8$ & $117.4^{\mathrm{a}} \pm 0.1$ & $*$ \\
\hline (-) epicatechin 3-O-gallate & $0.6^{\mathrm{bc}} \pm 0.0$ & $0.7^{\mathrm{bc}} \pm 0.0$ & $0.4^{\mathrm{c}} \pm 0.0$ & $1.6^{\mathrm{a}} \pm 0.0$ & $*$ \\
\hline \multicolumn{6}{|l|}{ Procyanidin dimers (mg/kg) } \\
\hline B1 & $10.0^{\mathrm{b}} \pm 0.0$ & $2.0^{\mathrm{d}} \pm 0.2$ & $14.0^{\mathrm{a}} \pm 0.5$ & $9.4^{\mathrm{c}} \pm 0.1$ & $*$ \\
\hline B2 & $74.2^{\mathrm{a}} \pm 0.0$ & $27.1^{\mathrm{c}} \pm 0.2$ & $46.3^{\mathrm{b}} \pm 2.3$ & $26.8^{\mathrm{c}} \pm 0.0$ & * \\
\hline B3 & $3.6^{\mathrm{b}} \pm 1.0$ & $3.0^{\mathrm{b}} \pm 0.1$ & $2.5^{\mathrm{c}} \pm 0.8$ & $4.2^{\mathrm{a}} \pm 0.1$ & $*$ \\
\hline B4 & $3.4^{\mathrm{b}} \pm 0.4$ & $1.9^{\mathrm{c}} \pm 0.1$ & $2.2^{\mathrm{c}} \pm 0.0$ & $4.3^{\mathrm{a}} \pm 0.2$ & $* *$ \\
\hline \multicolumn{6}{|c|}{ Procyanidin dimers gallate (mg/kg) } \\
\hline B1 3-O-gallate & $3.1^{\mathrm{b}} \pm 0.6$ & $0.8^{\mathrm{c}} \pm 0.1$ & $0.5^{\mathrm{c}} \pm 0.2$ & $4.6^{\mathrm{a}} \pm 0.0$ & $* *$ \\
\hline B2 3- $O$-gallate & $3.8^{\mathrm{ab}} \pm 0.9$ & $4.1^{\mathrm{ab}} \pm 0.3$ & $3.0^{\mathrm{bc}} \pm 0.5$ & $3.0^{\mathrm{bc}} \pm 0.3$ & $*$ \\
\hline B2 3'-O-gallate & $3.5^{\mathrm{b}} \pm 0.2$ & $5.2^{\mathrm{a}} \pm 0.3$ & $2.3^{\mathrm{c}} \pm 0.0$ & $2.9^{\mathrm{bc}} \pm 0.2$ & $*$ \\
\hline \multicolumn{6}{|l|}{ Procyanidins trimers (mg/kg) } \\
\hline $\mathrm{C} 1$ & $4.0^{\mathrm{b}} \pm 0.6$ & $1.9^{\mathrm{d}} \pm 0.1$ & $2.6^{\mathrm{c}} \pm 0.5$ & $8.6^{\mathrm{a}} \pm 0.3$ & $*$ \\
\hline Trimer 2 & $7.7^{\mathrm{a}} \pm 0.3$ & $1.7^{\mathrm{c}} \pm 0.0$ & $7.2^{\mathrm{a}} \pm 0.8$ & $2.8^{\mathrm{b}} \pm 0.5$ & $*$ \\
\hline \multicolumn{6}{|l|}{ Total small flavanols ( $\mathrm{mg} / \mathrm{kg})$} \\
\hline & $256.2^{\mathrm{a}} \pm 2.1$ & $121.5^{\mathrm{c}} \pm 2.2$ & $208.3^{\mathrm{b}} \pm 3.1$ & $258.4^{\mathrm{a}} \pm 1.8$ & * \\
\hline
\end{tabular}

Means within the same row followed by different letters are significantly different according to the Tukey test $(\mathrm{p}<0.05) ; *$ significant differences at $95 \%$ confidence level; $* *$ significant differences at $99.9 \%$ confidence level; I Harvest - first semester, years 2016 and 2017; II Harvest - second semester, years 2014 and 2016; results in mg/kg of skins in fresh weight.

According to the literature, in the extract of grape skins from traditional regions, compound $\mathrm{B} 1$ is usually the most plentiful (Ricardo-da-Silva et al., 1992; Jordão et al., 1998; Butkhup et al., 2010). However, Tyihák et al. (1998) also found higher concentrations of B2 in skins of Hungarian varieties. Since many factors influence the composition of procyanidins in grapes, the high concentrations of B2 in skins of grapes from São Francisco Valley may be related to the interaction of the variety and the 
characteristics of the region's "Terroir". Further studies are needed to better understand this behavior, especially in what concerns their biosynthetic pathway.

The total of small flavanols in the skins of the grapes varied mainly with the year of study and there was no tendency for a specific harvest season. The highest concentration present in the skins of the grapes from the first harvest season was $256.2 \mathrm{mg} / \mathrm{kg}$ and in the second harvest season was $258.4 \mathrm{mg} / \mathrm{kg}$, both in 2016.

\section{Wines - Chemical composition}

\section{Wine oenological parameters}

The classic analyse of the wines has been made and results are presented in Table $\mathrm{V} . \mathrm{pH}$, total and volatility acidity were not influenced by the grape harvest season. The $\mathrm{pH}$ varied from 3.9 up to 4.1 among the wine samples. The total acidity ranged from 4.3 up to $4.9 \mathrm{~g} / \mathrm{L}$ of tartaric acid. The $\mathrm{pH}$ value was considered high for red wines; in general, $\mathrm{pH}$ values between 3.6 and 4.5 are common in wines regions (Soares and Leão, 2009).

\section{TABLE V}

Effect of the harvest season on the composition of 'Touriga Nacional' wines in relation to classic analysis, global phenolic compounds, color, anthocyanins and other pigments

Efeito da época de colheita na composição dos vinhos 'Touriga Nacional' em relação à análises clássicas, compostos fenólicos globais, cor, antocianinas e outros pigmentos

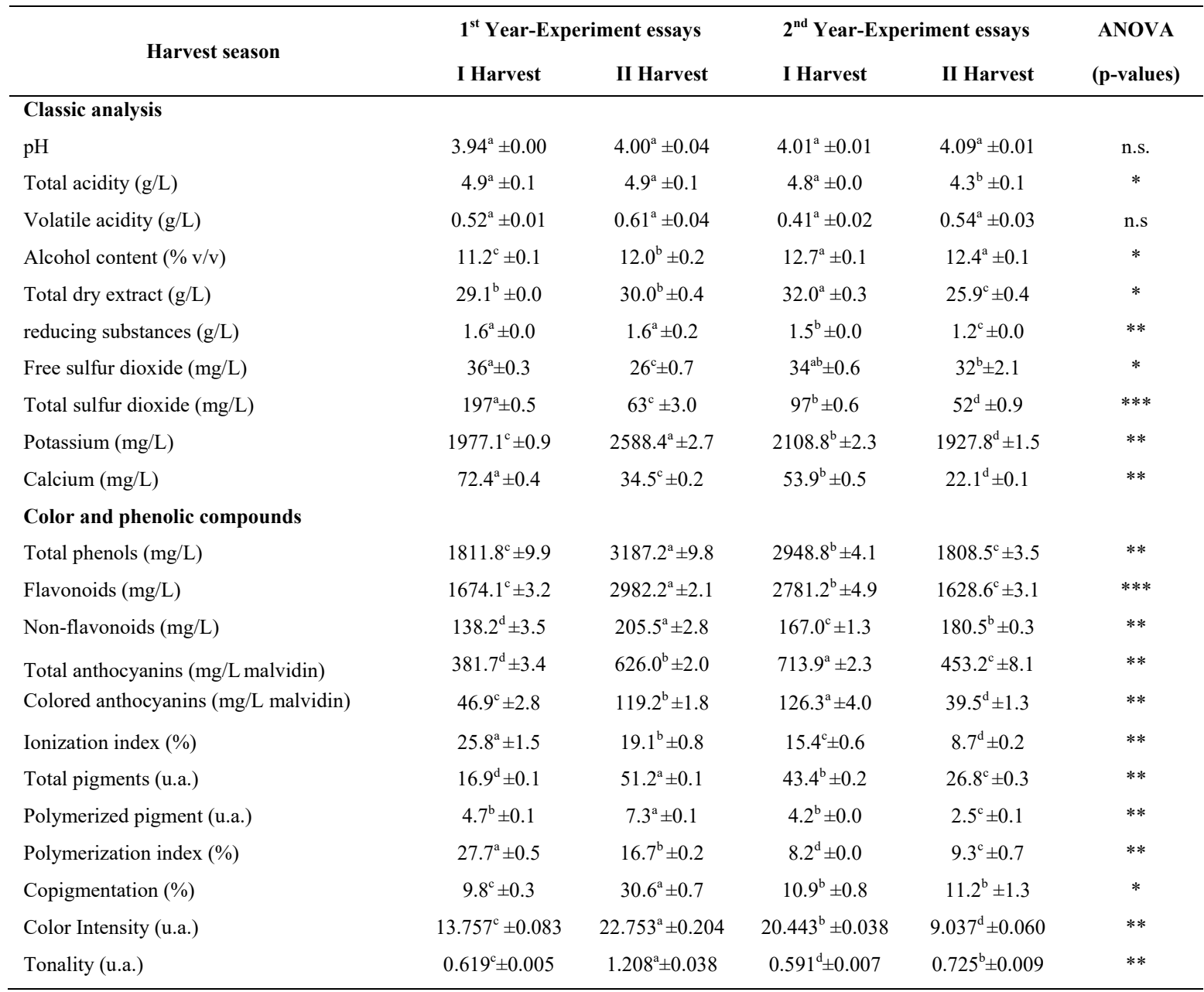

Means within the same row followed by different letters are significantly different according to the Tukey test ( $\mathrm{p}<0.05) ; *$ significant differences at $95 \%$ confidence level; ** significant differences at $99.9 \%$ confidence level; $* * *$ significant differences at $99.99 \%$ confidence level; I Harvest - first semester, years 2016 and 2017; II Harvest - second semester, years 2014 and 2016 ; total acidity (g/L tartaric acid); volatile acidity (g/L acetic acid); u.a. - absorbance units. 
In this study, it was possible to observe that the $\mathrm{pH}$ of the grape was significantly different in the second harvest season, being higher than in the first harvest, although the $\mathrm{pH}$ of the wines made from these grapes did not show any significantly difference between them. The manufacture process of the wines including alcoholic fermentation, malolactic fermentation and stability, modify the final profile of the wines which influences the $\mathrm{pH}$.

The alcoholic content in wines varied from 11.2 up to $12.7 \% \mathrm{v} / \mathrm{v}$ in the first semester's harvest and from 12.0 up to $12.4 \% \mathrm{v} / \mathrm{v}$ in the second harvest. It is possible to verify that there were no significant differences between the harvest seasons, but small variations between the years of the study.

The potassium concentration ranged from 1977.1 $\mathrm{mg} / \mathrm{L}$ up to $2108.8 \mathrm{mg} / \mathrm{L}$ in wines made from grapes harvested in the first harvest and from $1927.8 \mathrm{mg} / \mathrm{L}$ up to $2588.4 \mathrm{mg} / \mathrm{L}$ in wines made with grapes from the second harvest. The high concentrations of potassium in semi-arid tropical wines are attributed to soil fertilization with potassium-based fertilizers or even to the high natural concentration of potassium in the soils of the region (Soares and Leão, 2009).

Calcium concentration was influenced by the harvest season, with the highest concentrations in wines from grapes harvested in the first season, with $72.4 \mathrm{mg} / \mathrm{L}$ (2016) and $53.9 \mathrm{mg} / \mathrm{L}$ (2017). This may be associated with greater use of phytosanitary treatments against fungal diseases, which occur more frequently in the first half of the year in this region, due to periods of time with temperatures around $27{ }^{\circ} \mathrm{C}$ and more favorable to rainfall.

\section{Color and phenolic compounds in wines}

The results for total phenols, flavonoids and nonflavonoids are shown in Table V. Among these compounds, it is possible to observe that only the non-flavonoid compounds have been significantly affected by the harvest season, with higher contractions in the harvest made on the second semester. The other phenolic compounds varied among the years in which this study has been made, without a tendency for a specific harvest season. The highest total phenols content was $3187.2 \mathrm{mg} / \mathrm{L}$ and for flavonoids was $2982.2 \mathrm{mg} / \mathrm{L}$, both in the second harvest of 2014. The concentrations of total and flavonoid phenols reported in this study were higher than that reported by Vilela et al. (2016) for 'Touriga Nacional' monovarietal wines from the Douro region: $2290 \mathrm{mg} / \mathrm{L}$ of gallic acid (total phenols) and 1858 $\mathrm{mg} / \mathrm{L}$ of gallic acid for the flavonoid compounds.

The concentrations of total and colored anthocyanins are presented in Table V. It is possible to observe variations between the years of study, although a tendency for higher concentrations in a specific harvest season has not been found. The total anthocyanin concentrations ranged from 381.7 up to $713.9 \mathrm{mg} / \mathrm{L}$ of malvidin in wines made from grapes harvested in the first harvest season and ranged from 453.2 up to $626.0 \mathrm{mg} / \mathrm{L}$ of malvidin in the second harvest season.

The highest concentrations of the colored anthocyanins were $126.3 \mathrm{mg} / \mathrm{L}$ of malvidin in the first harvest season and $119.2 \mathrm{mg} / \mathrm{L}$ of malvidin in the wines elaborated with grapes harvested in the second season. For these compounds, the variation of concentrations was higher along the period of time of this study than the one detected on the different harvest seasons. The concentrations of total anthocyanins detected in this study were higher than those reported by Langbecker et al. (2018) for 'Touriga Nacional' wines in Southern region of Brazil. These authors have utilized two methods of maceration: traditional maceration and cold maceration, for which they quantified values of 310.0 $\mathrm{mg} / \mathrm{L}$ and $288.4 \mathrm{mg} / \mathrm{L}$, respectively. The concentrations of total and colored anthocyanins in this study were lower than those reported by Rodrigues et al. (2012) in wines made with the same variety, in the region of Dão, in Portugal. These authors have made their studies in a colder climate than the Brazilian region of this study. They have found concentrations of $715.0 \mathrm{mg} / \mathrm{L}$ and $154.0 \mathrm{mg} / \mathrm{L}$ for total and colored anthocyanins, respectively.

With regard to the total pigments, polymerized and the index of polymerization, the concentrations are presented in Table V. It is possible to observe that the harvest effect is not similar between the periods of time of this study. The highest concentration for the total pigments was 51.7 and for the polymerized was 7.3 , both in wines from the second harvest season in 2014. The polymerization index was higher in wines referring to 2016 first harvest season, being $27.7 \%$.

\section{Monomeric anthocyanins in wines}

The results of fourteen monomeric anthocyanins analysed are shown in Table VI. The harvest season effect was significant to twelve of the fourteen identified anthocyanins, with exception of two anthocyanins: the peonidin 3-O-coumarylglucoside and delphinidin 3-O-acetylglucoside. In relation to the non-acylated anthocyanins, cyanidin, peonidin and malvidin we have obtained higher concentrations in wines made in the first harvest season. The highest concentrations for these compounds found in this study were $3.2,5.3$ and $78.5 \mathrm{mg} / \mathrm{L}$, respectively. The delphinidin 3-O-glucoside was higher in wines made 
from grapes harvested in the second harvest season, with $3.3 \mathrm{mg} / \mathrm{L}$ (2016) and $3.2 \mathrm{mg} / \mathrm{L}$ (2014).

Among the five acetylated anthocyanins (Table VI), the data obtained indicate that the effect of the harvest season was significant, except for delphinidin 3-Oacetylglucoside. The anthocyanin cyanidin 3-Oacetylglucoside obtained higher concentrations in wines from grapes harvested in the first season, with amounts varying from 0.5 up to $1.2 \mathrm{mg} / \mathrm{L}$. The wines made in the second harvest season contained higher concentrations of peonidine, petunidine and malvidin 3-O-acetylglucoside, being their values of $2.3,3.3$ and $20.0 \mathrm{mg} / \mathrm{L}$, respectively.

TABLE VI

Profile of monomeric anthocyanins in semi-arid tropical wines containing 'Touriga National' variety, in four harvest seasons

Perfil das antocianinas monoméricas em vinhos tropicais semiáridos da variedade 'Touriga Nacional', em quatro épocas de colheita

\begin{tabular}{|c|c|c|c|c|c|}
\hline Harvest season & \multicolumn{2}{|c|}{$1^{\text {st }}$ Year-Experiment essays } & \multicolumn{2}{|c|}{$2^{\text {nd }}$ Year-Experiment essays } & $\begin{array}{l}\text { ANOVA } \\
\text { (p-values) }\end{array}$ \\
\hline \multicolumn{6}{|l|}{ Non-acylated anthocyanins (mg/L) } \\
\hline Delphinidin 3-O-glucoside & $1.7^{\mathrm{c}} \pm 0.1$ & $3.2^{\mathrm{a}} \pm 0.0$ & $2.5^{\mathrm{b}} \pm 0.6$ & $3.3^{\mathrm{a}} \pm 0.0$ & $* *$ \\
\hline Cyanidin 3-O-glucoside & $1.0^{\mathrm{c}} \pm 0.1$ & $0.4^{\mathrm{d}} \pm 0.0$ & $3.2^{\mathrm{a}} \pm 0.0$ & $1.4^{\mathrm{b}} \pm 0.0$ & $* *$ \\
\hline Petunidin 3-O-glucoside & $0.7^{\mathrm{c}} \pm 0.0$ & $2.4^{\mathrm{b}} \pm 0.1$ & $3.9^{\mathrm{a}} \pm 4.5$ & $2.2^{\mathrm{b}} \pm 0.0$ & $*$ \\
\hline Malvidin 3-O-glucoside & $41.5^{\mathrm{c}} \pm 2.7$ & $28.2^{\mathrm{d}} \pm 0.7$ & $78.5^{\mathrm{a}} \pm 0.2$ & $53.6^{\mathrm{b}} \pm 0.5$ & $* * *$ \\
\hline \multicolumn{6}{|l|}{ Acetylated anthocyanins (mg/L) } \\
\hline Peonidin 3-O-acetylglucoside & $0.7^{\mathrm{c}} \pm 0.0$ & $2.3^{\mathrm{a}} \pm 0.2$ & $0.6^{\mathrm{c}} \pm 0.1$ & $1.9^{\mathrm{b}} \pm 0.2$ & $*$ \\
\hline Malvidin 3-O-acetylglucoside & $7.2^{\mathrm{d}} \pm 0.1$ & $12.3^{\mathrm{b}} \pm 0.2$ & $8.3^{\mathrm{c}} \pm 0.2$ & $20.0^{\mathrm{a}} \pm 0.6$ & * \\
\hline \multicolumn{6}{|l|}{ Coumaroylated anthocyanins (mg/L) } \\
\hline Peonidin 3-O-coumarylglucoside & $0.5^{\mathrm{ab}} \pm 0.0$ & $0.7^{\mathrm{a}} \pm 0.0$ & $0.0^{\mathrm{b}} \pm 0.0$ & $0.6^{\mathrm{ab}} \pm 0.0$ & n.s. \\
\hline Petunidin 3-O-coumarylglucoside & $0.4^{\mathrm{d}} \pm 0.0$ & $6.0^{\mathrm{a}} \pm 0.2$ & $1.0^{\mathrm{c}} \pm 0.1$ & $2.4^{\mathrm{b}} \pm 0.0$ & $* *$ \\
\hline Delphinidin 3-O-coumarylglucoside & $0.6^{\mathrm{b}} \pm 0.0$ & $0.0^{\mathrm{c}} \pm 0.0$ & $1.5^{\mathrm{a}} \pm 0.1$ & $0.0^{\mathrm{c}} \pm 0.0$ & $*$ \\
\hline Malvidin 3-O-coumarylglucoside & $5.1^{\mathrm{b}} \pm 0.0$ & $3.9^{\mathrm{c}} \pm 0.0$ & $5.9^{\mathrm{a}} \pm 0.0$ & $5.4^{\mathrm{ab}} \pm 0.3$ & $* *$ \\
\hline \multicolumn{6}{|l|}{ Total monomeric anthocyanins $(\mathrm{mg} / \mathrm{L})$} \\
\hline
\end{tabular}

Means within the same row followed by different letters are significantly different according to the Tukey test ( $\mathrm{p}<0.05$ ); n.s. not significant; $*$ significant differences at $95 \%$ confidence level; $* *$ significant differences at $99.9 \%$ confidence level; $* * *$ significant differences at $99.99 \%$ confidence level; I Harvest - first semester, years 2016 and 2017; II Harvest - second semester, years 2014 and 2016.

The harvest effect was significant for coumaroylated anthocyanins (Table VI), except for peonidin. The anthocyanins delphinidin and malvidin presented higher concentrations in the first harvest season, with the highest levels being 1.5 and $5.9 \mathrm{mg} / \mathrm{L}$, respectively. The acetylglucosylated petunidin was higher in wines from the second harvest season, with the highest concentration of $6.0 \mathrm{mg} / \mathrm{L}$.

The total monomeric anthocyanins content was influenced by harvest season. High concentrations were reached in the first season of year, where was possible to detect $67.8 \mathrm{mg} / \mathrm{L}$ (in 2016) and 113.1 $\mathrm{mg} / \mathrm{L}$ (in 2017). In this study, the concentrations in 'Touriga Nacional' wines were lower than those reported by Mateus et al. (2001) in experimental wines using the same variety in Douro region (with an altitude of $300-350 \mathrm{~m}$ ). These authors have quantified $412.64 \mathrm{mg} / \mathrm{L}$ for total anthocyanins.

In this study, it was possible to observe that the composition of monomeric anthocyanins in grapes and wines were influenced by the harvest season (Tables I and VI) but the profiles between grapes and wines were different. This fact can be related to a better extraction during the maceration process 
because a larger volume of grapes was processed. In addition to the extractability factor, anthocyanins are located within vacuoles of the skin cells as well as in cell walls, which are barriers to their extraction. These barriers are composed by complex polysaccharides (pectins) that highly interfere in the extraction process because they must be degraded in order to allow the passage and release through the walls. This degradation allows a better extraction and diffusion into the wine. Since this is a complicated process, the total extract of anthocyanins from grapes is difficult to obtain (Amrani Joutei and Glories, 1995; Romero-Cascales et al., 2005). According to the literature, the red grapes are the exclusive source of monomeric anthocyanins and therefore their composition profile corresponds to that of red wines (Revilla et al., 2001; Mateus et al., 2002; Mulinacci et al., 2008; He et al., 2012).

\section{Condensed tannins in wines}

The results for monomeric, oligomeric and polymeric fractions of condensed tannins in 'Touriga Nacional' are presented in Table VII. They show a harvest effect on the condensed tannins composition in 'Touriga Nacional' wines. The monomeric and oligomeric tannins presented higher values in wines from the second harvest season, while the polymer tannins reached higher values in the first harvest season. The highest concentration observed for monomeric flavan-3-ols was $31.6 \mathrm{mg} / \mathrm{L}$ (2014), for oligomeric it was $796.4 \mathrm{mg} / \mathrm{L}$ (2016) and polymeric tannins have reached $1240.9 \mathrm{mg} / \mathrm{L}$ (2016). The concentrations observed in this study for the oligomeric and polymeric tannins in 'Touriga Nacional' wine were higher than those reported by Cosme et al. (2009) also in 'Touriga Nacional' wines, produced in Lisbon region, reporting concentrations ranging from 62.3 up to $73.9 \mathrm{mg} / \mathrm{L}$ for oligomeric tannins and 288.3 up to $670.0 \mathrm{mg} / \mathrm{L}$ for polymeric tannins.

Regarding the total condensed tannins, the concentrations varied between the years of study and the harvest season effect was not uniform. The highest concentration of total condensed tannins has been detected in wine samples from 2016 second harvest season, with $1938.7 \mathrm{mg} / \mathrm{L}$. The high concentrations of condensed tannins in the wines is related to the content present in the seeds and skins (Table II). According to Kennedy et al. (2000) and Downey et al. (2003), the extraction of tannins in wines may be dependent on the composition and amount of tannins in the berries of a vintage.
With regard to the tanning power (Table VII), it is possible to observe a direct relationship between the concentration of total condensed tannins. The highest tanning power was obtained for 'Touriga Nacional' wine from the second harvest season (2016) with $351.7 \mathrm{NTU} / \mathrm{mL}$, this wine also presented the highest levels of tannins: $1938.7 \mathrm{mg} / \mathrm{L}$.

\section{Monomeric and small oligomeric flavanols in wines}

The concentrations of monomeric flavanols and small weight molecules such as procyanidins are shown in Table VII. The harvest effect is significant for most of the studied chemical compounds. The monomeric flavanols catechin and epicatechin obtained higher values in the wines from the first harvest season, presenting the highest concentrations of $13.2 \mathrm{mg} / \mathrm{L}$ and $18.1 \mathrm{mg} / \mathrm{L}$, respectively. The concentration obtained in this study for these compounds was higher than those reported by Mateus et al. (2001) for wines from Douro region: 3.53 and $4.89 \mathrm{mg} / \mathrm{L}$ for catechin and epicatechin, respectively. They were also lower than those reported by Padilha et al. (2016) for commercial wines from 'Touriga Nacional' from São Francisco Valley for catechin compound, in which they have quantified $53.9 \mathrm{mg} / \mathrm{L}$ and $5.13 \mathrm{mg} / \mathrm{L}$ for epicatechin compounds.

The profile of dimeric procyanidins is presented in Table VII. The wines made with grapes harvested in the first harvest season contained high concentrations of B2, being in 2016, $14.5 \mathrm{mg} / \mathrm{L}$ and in 2017, 16.3 $\mathrm{mg} / \mathrm{L}$. The wine from the second harvest season was characterized by the higher concentration of dimers: B1 (9.3 and $12.7 \mathrm{mg} / \mathrm{L}), \mathrm{B} 3(2.8$ and $3.8 \mathrm{mg} / \mathrm{L}), \mathrm{B} 4$ $(5.0$ and $6.2 \mathrm{mg} / \mathrm{L}), \mathrm{B} 2$ 3-O-gallate $(0.9$ and 1.6 $\mathrm{mg} / \mathrm{L})$ and B2 3'-O-gallate (1.4 and $1.5 \mathrm{mg} / \mathrm{L})$.

Regarding the trimeric procyanidins, the effect of harvest season was significant for 'Touriga Nacional' wines produced in tropical semi-arid climate. The wines made with grapes from the second harvest season contained significant quantities, being the highest concentrations of $2.6 \mathrm{mg} / \mathrm{L}(\mathrm{C} 1)$ and $2.8 \mathrm{mg} / \mathrm{L}$ (Trimer 2). The concentration of procyanidin $\mathrm{C} 1$ was lower than that reported by Mateus et al. (2001) for the same variety in Douro region. However, for procyanidin $\mathrm{T} 2$ the concentration was higher than the one reported by Monagas et al. (2003) in Portuguese wines containing 'Tempranillo', 'Graciano' and 'Cabernet Sauvignon' varieties (concentrations ranging from $0.67 \mathrm{mg} / \mathrm{L}$ up to $1.09 \mathrm{mg} / \mathrm{L}$ ), and lower than those quantified by Fanzone et al. (2011) in five red varieties in Argentina (concentrations ranging from 8.1 up to $15.2 \mathrm{mg} / \mathrm{L}$ ). 


\section{TABLE VII}

Condensed tannins, monomeric flavanols and procyanidins in semi-arid tropical wines containing Touriga National variety, in four harvest seasons

Taninos condensados, flavanóis monoméricos e procianidinas em vinhos tropicais semiáridos da variedade Touriga Nacional, em quatro épocas de colheita

\begin{tabular}{|c|c|c|c|c|c|}
\hline \multirow{2}{*}{ Harvest season } & \multicolumn{2}{|c|}{$1^{\text {st }}$ Year-Experiment essays } & \multicolumn{2}{|c|}{$2^{\text {nd }}$ Year-Experiment essays } & \multirow{2}{*}{$\begin{array}{l}\text { ANOVA } \\
\text { (p-values) }\end{array}$} \\
\hline & I Harvest & II Harvest & I Harvest & II Harvest & \\
\hline Monomeric & $10.0^{\mathrm{d}} \pm 0.2$ & $31.6^{\mathrm{a}} \pm 1.7$ & $11.6^{\mathrm{c}} \pm 0.3$ & $18.6^{\mathrm{b}} \pm 0.6$ & $*$ \\
\hline Oligomeric & $200.9^{c} \pm 0.2$ & $678.4^{\mathrm{b}} \pm 5.4$ & $106.9^{\mathrm{d}} \pm 4.9$ & $796.4^{\mathrm{a}} \pm 2.7$ & $* *$ \\
\hline \multicolumn{6}{|l|}{ Tanning Power (NTU/mL $\left.\mathbf{m}^{1}\right)$} \\
\hline & $250.0^{\mathrm{b}} \pm 8.8$ & $212.7^{\mathrm{d}} \pm 1.8$ & $219.5^{\mathrm{c}} \pm 1.6$ & $351.7^{\mathrm{a}} \pm 5.6$ & $* *$ \\
\hline \multicolumn{6}{|l|}{ Monomeric flavanols (mg/L) } \\
\hline$(+)$ catechin & $13.2^{\mathrm{a}} \pm 0.2$ & $4.7^{\mathrm{d}} \pm 0.0$ & $12.5^{\mathrm{a}} \pm 0.0$ & $6.5^{\mathrm{c}} \pm 0.3$ & $*$ \\
\hline $\mathrm{B} 1$ & $2.3^{\mathrm{c}} \pm 0.1$ & $9.3^{\mathrm{b}} \pm 0.9$ & $1.6^{\mathrm{d}} \pm 0.0$ & $12.7^{\mathrm{a}} \pm 0.3$ & * \\
\hline $\mathrm{B} 2$ & $14.5^{\mathrm{c}} \pm 0.3$ & $8.2^{\mathrm{d}} \pm 0.2$ & $16.3^{\mathrm{a}} \pm 0.5$ & $15.8^{\mathrm{b}} \pm 0.4$ & $*$ \\
\hline B3 & $1.3^{\mathrm{c}} \pm 0.0$ & $3.8^{\mathrm{a}} \pm 0.2$ & $1.0^{\mathrm{c}} \pm 0.0$ & $2.8^{\mathrm{b}} \pm 0.1$ & $*$ \\
\hline B4 & $0.1^{\mathrm{c}} \pm 0.0$ & $6.2^{\mathrm{a}} \pm 0.5$ & $0.2^{\mathrm{c}} \pm 0.0$ & $5.0^{\mathrm{b}} \pm 0.8$ & $*$ \\
\hline \multicolumn{6}{|c|}{ Procyanidins dimers gallate $(\mathrm{mg} / \mathrm{L})$} \\
\hline B1 3-O-gallate & $1.0^{\mathrm{a}} \pm 0.0$ & $0.1^{\mathrm{b}} \pm 0.0$ & $1.0^{\mathrm{a}} \pm 0.0$ & $0.8^{\mathrm{a}} \pm 0.0$ & $*$ \\
\hline B2 3-O-gallate & $0.6^{\mathrm{c}} \pm 0.0$ & $1.6^{\mathrm{a}} \pm 0.1$ & $0.4^{\mathrm{c}} \pm 0.1$ & $0.9^{\mathrm{b}} \pm 0.1$ & $*$ \\
\hline B2 3'-O-gallate & $0.9^{\mathrm{b}} \pm 0.0$ & $1.4^{\mathrm{a}} \pm 0.0$ & $0.7^{\mathrm{b}} \pm 0.0$ & $1.5^{\mathrm{a}} \pm 0.2$ & $*$ \\
\hline
\end{tabular}

Means within the same row followed by different letters are significantly different according to the Tukey test ( $\mathrm{p}<0.05) ; *$ significant differences at $95 \%$ confidence level; ${ }^{* *}$ significant differences at $99.9 \%$ confidence level; I Harvest - first semester, years 2016 and 2017; II Harvest - second semester, years 2014 and 2016.

Concentration of flavanols seems to be influenced by the climatic variations seen every year. In this study, the highest concentration was $63.7 \mathrm{mg} / \mathrm{L}$ in a wine made on the second harvest season, in 2016. The procyanidins are transferred exclusively into the must during wine-making operations, such as crushing, maceration and fermentation (Garrido and Borges, 2013). The extraction does not occur completely (Bindon et al, 2010), and depends mainly on the cultivar, viticulture practices and vinification techniques (Mulero et al., 2009; Orduña, 2010; Cejudo-Bastante et al., 2011; Garrido and Borges, 2013).

\section{Wines - Sensory analysis}

The sensory profile of 'Touriga Nacional' wines produced in tropical and semi-arid region of Brasil, and made in four harvest seasons is shown in Table VIII and Figure 2. The color visual attribute had high scores in wines from 2017 first harvest season. According to the chemical analyses, these wines contained higher concentrations of total and colored anthocyanins (Table V), being $713.9 \mathrm{mg} / \mathrm{L}$ of malvidin and $126.3 \mathrm{mg} / \mathrm{L}$, respectively. 


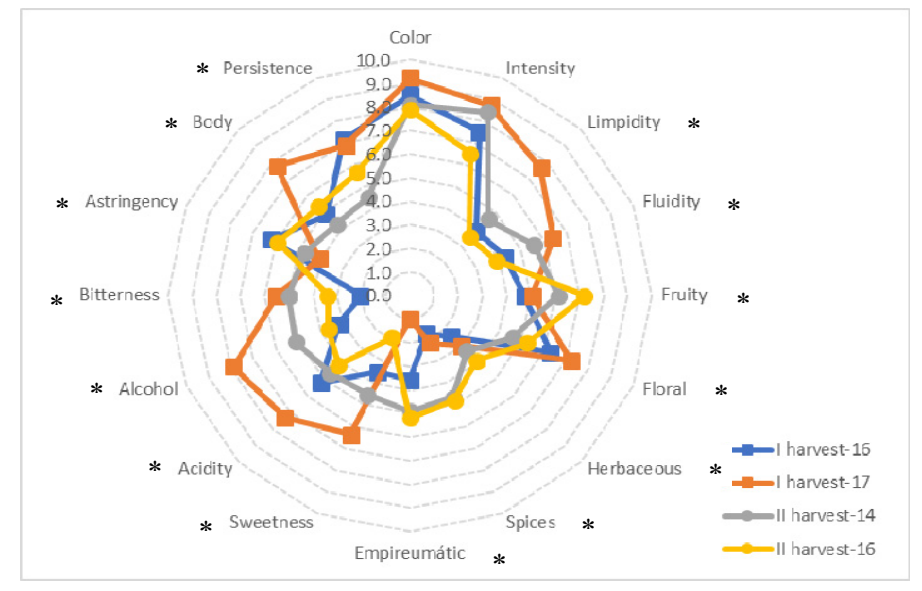

Figure 2. Sensory profile of semi-arid tropical wines containing 'Touriga Nacional' variety, in four harvest seasons. I harvest - harvest made on the first semester; II harvest - harvest made on the second semester; 14,15 and 16 - years of the experiment; * significant differences $\mathrm{p}<0.05$.

Perfil sensorial de vinhos tropicais semiáridos da variedade 'Touriga Nacional', em quatro épocas de colheita. I Colheita - colheita do primeiro semestre; II Colheita - colheita do segundo semestre; 14, 15 e 16 - anos do ensaio; * diferenças significativas $p<0,05$.

\section{Table VIII}

Sensory profile of semi-arid tropical wines containing Touriga Nacional variety, in four harvest seasons

Perfil sensorial de vinhos tropicais semiáridos Touriga Nacional em quatro épocas de colheita

\begin{tabular}{|c|c|c|c|c|}
\hline \multirow[t]{2}{*}{ Harvest season } & \multicolumn{2}{|c|}{$\begin{array}{c}1^{\text {st }} \text { Year-Experiment } \\
\text { essay }\end{array}$} & \multicolumn{2}{|c|}{$\begin{array}{c}2^{\text {nd }} \text { Year-Experiment } \\
\text { essays }\end{array}$} \\
\hline & I Harvest & II Harvest & I Harvest & II Harvest \\
\hline \multicolumn{5}{|l|}{ Visual profile } \\
\hline Color & $8.5^{\mathrm{a}} \pm 0.9$ & $8.1^{\mathrm{a}} \pm 0.5$ & $9.2^{\mathrm{a}} \pm 0.7$ & $8.8^{\mathrm{a}} \pm 1.0$ \\
\hline Intensity & $7.5^{\mathrm{ab}} \pm 0.9$ & $8.4^{\mathrm{a}} \pm 0.9$ & $8.7^{\mathrm{a}} \pm 0.8$ & $6.5^{\mathrm{b}} \pm 1.1$ \\
\hline Limpidity & $3.9^{\mathrm{b}} \pm 1.4$ & $4.6^{b} \pm 1.7$ & $7.6^{\mathrm{a}} \pm 0.8$ & $3.5^{\mathrm{b}} \pm 1.2$ \\
\hline Fluidity & $4.3^{\mathrm{b}} \pm 0.9$ & $5.6^{\mathrm{b}} \pm 1.2$ & $8.4^{\mathrm{a}} \pm 0.6$ & $3.9^{\mathrm{bc}} \pm 1.1$ \\
\hline \multicolumn{5}{|c|}{ Aromatic attributes } \\
\hline Fruity & $4.7^{\mathrm{b}} \pm 1.5$ & $6.5^{\mathrm{a}} \pm 1.6$ & $5.0^{\mathrm{b}} \pm 0.7$ & $6.1^{\mathrm{a}} \pm 2.0$ \\
\hline Floral & $6.3^{\mathrm{ab}} \pm 1.3$ & $4.6^{\mathrm{b}} \pm 1.1$ & $7.2^{\mathrm{a}} \pm 1.0$ & $5.3^{\mathrm{b}} \pm 1.3$ \\
\hline Herbaceous & $2.4^{\mathrm{b}} \pm 1.1$ & $2.3^{\mathrm{b}} \pm 1.7$ & $3.2^{\mathrm{a}} \pm 2.0$ & $3.9^{\mathrm{a}} \pm 0.9$ \\
\hline Spices & $1.8^{\mathrm{b}} \pm 0.9$ & $4.7^{\mathrm{a}} \pm 1.4$ & $2.2^{\mathrm{b}} \pm 0.7$ & $4.8^{\mathrm{a}} \pm 1.3$ \\
\hline Empyreumatic & $3.6^{\mathrm{b}} \pm 0.7$ & $4.9^{\mathrm{a}} \pm 0.8$ & $1.0^{\mathrm{c}} \pm 0.6$ & $5.2^{\mathrm{a}} \pm 1.1$ \\
\hline \multicolumn{5}{|l|}{ Taste attributes } \\
\hline Sweetness & $3.5^{\mathrm{b}} \pm 1.0$ & $4.6^{\mathrm{b}} \pm 2.0$ & $6.4^{\mathrm{a}} \pm 1.5$ & $1.9^{\mathrm{c}} \pm 0.9$ \\
\hline Acidity & $5.2^{\mathrm{b}} \pm 1.7$ & $4.7^{\mathrm{bc}} \pm 1.8$ & $7.3^{a} \pm 1.3$ & $4.2^{\mathrm{c}} \pm 1.8$ \\
\hline Alcohol & $3.2^{\mathrm{c}} \pm 1.0$ & $5.1^{\mathrm{b}} \pm 0.6$ & $7.9^{\mathrm{ab}} \pm 0.7$ & $3.6^{\mathrm{c}} \pm 1.4$ \\
\hline Bitterness & $1.0^{\mathrm{c}} \pm 0.6$ & $5.0^{\mathrm{a}} \pm 1.8$ & $5.5^{\mathrm{a}} \pm 1.3$ & $3.7^{\mathrm{b}} \pm 1.0$ \\
\hline Astringency & $6.2^{\mathrm{a}} \pm 1.1$ & $4.7^{\mathrm{b}} \pm 1.0$ & $4.1^{b} \pm 1.3$ & $5.9^{\mathrm{a}} \pm 2.0$ \\
\hline Body & $4.9^{\mathrm{bc}} \pm 0.9$ & $4.3^{\mathrm{c}} \pm 1.0$ & $7.8^{\mathrm{a}} \pm 1.6$ & $5.3^{\mathrm{b}} \pm 1.2$ \\
\hline Persistence & $7.2^{\mathrm{a}} \pm 1.5$ & $6.9^{\mathrm{a}} \pm 1.7$ & $4.5^{\mathrm{c}} \pm 0.7$ & $5.7^{\mathrm{b}} \pm 1.8$ \\
\hline
\end{tabular}

Means within the same row followed by different letters are significantly different according to the Tukey test $(\mathrm{p}<0.05)$; I Harvest - first semester, years 2016 and 2017; II Harvest - second semester, years 2014 and 2016.

Regarding the olfactory profile, wines made with grapes harvested in the first harvest season obtained higher scores for floral aroma. Floral descriptor in 'Touriga Nacional' wines was also identified in other studies reported in the literature (Falqué et al., 2004; De Pinho et al., 2007; Vilanova et al., 2012). 'Touriga Nacional' wines presented higher levels of terpene compounds as well as nor-isoprenoids in $\mathrm{C} 13$ compared to other wines produced from other red varieties, which promotes greater floral aroma (Barbosa et al., 2003; Oliveira et al., 2006). The climatic conditions in the first harvest of the year seem to have a positive effect on the synthesis of terpene compounds on grapes and, consequently in their wines, but more studies must be carried out in order to better understand this effect. The wines from the second harvest season of the year were characterized by higher intensity of fruity, spicy and empyreumatic aromas. These aromas have been identified in other studies with 'Touriga Nacional' wines (Falqué et al., 2004; Vilela et al., 2016; Langbecker et al., 2018).

Concerning the taste attributes, sweetness, acidity and alcohol, the scores varied between the harvest season, but the highest ones were obtained for 2017 I harvest wines, being in accordance with the physicochemical analyses previously described. Regarding the bitterness attribute, the highest scores were found on 2017 I harvest wines and can be justified by their high ethanol content: $12.7 \% \mathrm{v} / \mathrm{v}$ (Table V). According to Noble (1994), the bitterness increases with the increasing of ethanol content.

The astringency had higher scores in wines made in 2016, in both harvest seasons. According to the physicochemical analyses (Table VII), these wines contained higher concentrations of total condensed tannins, with $1451.8 \mathrm{mg} / \mathrm{L}$ (I harvest) and 1938.7 $\mathrm{mg} / \mathrm{L}$ (II harvest), as well as high tanning power 
contents, with $250 \mathrm{mg} / \mathrm{L}$ and $351.7 \mathrm{mg} / \mathrm{L}$ for I harvest and II harvest, respectively. The astringency of wines is primarily driven by proanthocyanidins, also called condensed tannins (Sáenz-Navajas et al., 2012; Brandão et al., 2014).

The bitterness attribute obtained higher scores in wines from 2017 first harvest season, followed the latter in the second harvest made in 2014, a factor that may be related to higher concentration of flavonoid compounds on wines (Table V). According to Singleton (1995) flavonoid phenols present in wines are the main cause of their bitterness.

\section{CONCLUSIONS}

This study pointed out the effect of the harvest season on some chemical compounds of grapes from 'Touriga Nacional' cv. from a semi-arid region of northeastern Brazil.

Grapes harvested on the first harvest season (first semester) contained higher total acidity, higher concentrations of tartaric and malic acids, nonflavonoid phenols, some monomeric anthocyanins (delphinidin, cyanidin, petunidin, petunidin 3-Oacetylglucoside, delphinidin 3-O-acetylglucoside and malvidin 3-O-coumarylglucoside), flavanols (catechin, epicatechin and B2 3 '-O-gallate) and total flavanols in the seeds. In addition, the skins also presented high content of flavanols B1, B2 and Trimer 2.

The grapes from the second harvest season (second semester) contained higher levels of $\mathrm{pH}$, cyanidin 3$O$-acetylglucoside, malvidin 3-O-acetylglucoside and peonidin 3-O-coumarylglucoside, $\mathrm{mDP}$ from skins and seeds extracts. Condensed tannins, oligomeric tannins and, B 2 3'-O-gallate, in the skins, flavanols (B1 and T2) were found on seed extracts.

Concerning the composition of 'Touriga Nacional' wines, we can conclude that some compounds were influenced by the harvest season. Wines made from grapes harvested in the first semester contained higher concentrations of calcium, some non-acylated anthocyanins (cyanidin, peonidin and malvidin), cyanidin 3-O-acetylglucoside, delphinidin and malvidin 3-O-coumarylglucoside, polymeric tannins, catechin, epicatechin and procyanidin B2.

Wines made with grapes harvested in the second semester of each studied year presented higher concentrations of non-flavonoid phenols, percentage of copigmentation, monomeric anthocyanins (delphinidin 3-O-glucoside, peonidin 3-O- acetylglucoside, petunidin 3-O-acetylglucoside, malvidin 3-O-acetylglucoside and petunidin 3-Ocoumarylglucoside), monomeric and oligomeric condensed tannins, as well as procyanidins B1, B3, $\mathrm{B} 4, \mathrm{~B} 2 \mathrm{3}-\mathrm{O}$-gallate, $\mathrm{B} 23^{\prime}-\mathrm{O}$-gallate, and trimers $\mathrm{C} 1$ and $\mathrm{T} 2$.

According to the sensory analysis made, the effect of harvest season was significant for most of the attributes. Wines made with grapes from the first harvest season were characterized by higher scores for the attributes limpidity, floral aroma, acidity, persistence and body. Wines obtained from grapes harvested in the second harvest season had higher scores for aromatic attributes (fruity, herbaceous, spices and empireumatic).

This study allowed confirm that the harvest season has influenced the grapes chemical composition and consequently the wines made from them, indicating that important adaptations need to be made on the methods of manufacture for each vintage. Thus, it would be interesting to carry out studies with different tests of maceration times and possible application of oenological tannins during the elaboration process, including desirably a microoxygenation input during wine maturation. In addition, an evaluation of aromatic profile by gas chromatography would be interesting, once the wines obtained had distinct aromatic profile for each harvest season, which may indicate a specific characteristic of this "terroir".

\section{ACKNOWLEDGMENTS}

This research was supported by Brazilian companies: Coordenação de Aperfeiçoamento de Pessoal de Nível Superior (Capes - 6070/1302); Embrapa Semiarid, CNPq project (403438/2013-6) and Rio Sol/Global Wines (Lagoa Grande, Pernambuco).

In Portugal, we thank the research center in Instituto Superior de Agronomia: Linking Landscape, Environment, Agriculture and Food - LEAF (UID/AGR/04129/2013) and FCT by scholarship of Egipto, R. (SFRH/BD/128847/2017).

\section{REFERENCES}

Amrani Joutei K., Glories Y. 1995. Tannins and anthocyanins of grape berries: Localization and extraction technique. Rev. Fr. Oenol., 153, 28-31.

Barbosa A., Silva Ferreira A.C., Guedes de Pinho P., Pessanha M., Vieira M., Soares Franco J.M., Hogg T., 2003. Determination of monoterpenes on portuguese wine varieties. 584-588. In: 5th Symposium of Enology, Portugal. 
Bindon KA., Smith PA. and Kennedy JA., 2010. Interaction between grape-derived proanthocyanidins and cell wall material. 1 . Effect on proanthocyanidin composition and molecular mass. $J$. Agric. Food Chem., 58, 2520-2528.

Böhm J., 2007. Portugal Vitícola, o grande livro das castas. Chaves Ferreira Publicações, S.A., Portugal.

Bordiga M., Travaglia F., Locatelli M., Coisson J. D., Arlorio M., 2011. Characterisation of polymeric skin and seeds proanthocyanidins during ripening in six Vitis vinífera L. cv. Food Chem., 127, 180-187.

Boulton R., 2001. The copigmentation of anthocyanins and its role in the color of red wine: A Critical Review. Am. J. Enol. Vitic., 52, 67-80.

Bourzeix M., Weyland D., Heredia N., 1986. Étude des catéchines et des procyanidols de la grappe de raisin, de vin et d'autres dérivés de la vigne, 1171-1254.

Brandão E., Soares S., Mateus N., de Freitas V., 2014. In Vivo Interactions between Procyanidins and Human Saliva Proteins: Effect of Repeated Exposuresto Procyanidins Solution. J. Agric. Food Chem., 62, 9562-9568.

Brites J., Pedroso V., 2000. Castas recomendadas da Região do Dão, da Direção Regional de Agricultura da Beira Litoral e Centro de estudos vitivinícolas do Dão, vol. 8, 23 p. Direção Regional de Agricultura e Pescas do Dão, Nelas, Portugal.

Butkhup L., Chowtivannakul S., Gaensakoo R., Prathepha P., Samappito S., 2010. Study of the Phenolic Composition of Shiraz Red Grape Cultivar (Vitis viniferaL.) Cultivated in North-eastern Thailand and its Antioxidant and Antimicrobial Activity. S. Afr. J. Enol. Vitic., 31, 89-98.

Camargo U. A., Tonietto J., Hoffmann A., 2011. Advances in grape culture in Brazil. Rev. Bras. Frutic., 33, 144-149.

Carbonneau A., Champagnol F., 1993. Nouveaux systemes de culture integre Du vignoble. Programme AIR-3-CT 93.

Cejudo-Bastante M. J., Pérez-Coello M. S., Hermosín-Gutiérrez I., 2011. Effect of wine micro-oxygenation treatment and storage period on colour-related phenolics, volatile composition and sensory characteristics. LWT- Food Sci. Technol., 44, 866-874.

Cosme F., Ricardo-da-Silva J. M., Laureano O., 2009. Tannin profiles of Vitis vinifera L. cv. red grapes growing in Lisbon and from their monovarietal wines. Food Chem., 112, 197-204.

De Freitas V., Mateus N., 2001. Structural features of procyanidin interactions with salivary proteins. J. Agric. Food Chem., 49, 940945 .

De Pinho P. G., Falque E., Castro M., Silva H. O. E., Machado B., Ferreira A. C. S., 2007. Further insights into the floral character of touriga nacional wines. J. Food Sci., 72: S396-S401.

Downey M.O., Harvey J.S. and Robinson S.P., 2003. Analysis of tannins in seeds and skins of Shiraz grapes throughout berry development. Aust. J. Grape Wine Res., 9, 15-27.

Downey, M.O., Dokoozlian, N.K., Krstic, M., 2006. Cultural practice and environmental impacts on the flavonoid composition of grapes and wine: A review of recent research. Am. J. Enol. Vitic., 57, 257-268.

Falqué E., Ferreira A. C., Hoog T., Guedes-Pinho P., 2004. Determination of aromatic descriptors of TourigaNacional wines by sensory descriptive analysis. Flavour Fragr. J., 19, 298-302.

Fanzone, M., Zamora F., Jofré V., Assof M., Gómez-Cordóves C., Peña-Neira A., 2011. Phenolic Characterization of red wines from different grape varieties cultivated in Mendonza Province (Argentina). J. Sci. Food Agric., 92, 704-718.

Ferrer-Gallego R., Hernández-Hierro J. M., Rivas-Gonzalo J. C., Escribano-Bailon M. T., 2012. Influence of climatic conditions on the phenolic composition of Vitis vinifera L. cv. Graciano. Anal. Chim. Acta, 732, 73-77.

Ford C. M., 2012. The Biochemistry of the Grape Berry. 67-88 p. Scopus, USA.

Fuleki, T., Ricardo-da-Silva, J. M., 1997. Catechin and procyanidin composition of seeds from grape cultivars grown in Ontario. $J$. Agric. Food Chem. 45, 1156-1160.

Garrido J., Borges F., 2013. Wine and grape polyphenols - A chemical perspective. Food Res. Int., 54, 1844-1858.

Gutiérrez-Gamboa G., Garde-Cerdán T., Portu J., MorenoSimunovic Y., Martínez-Gil, A.M., 2017. Foliar nitrogen application in Cabernet Sauvignon vines: Effects on wine flavonoid and amino acid content. Food Res. Int., 96, 46-53.

Gutiérrez-Gamboa, G., Moreno-Simunovic, Y., 2018. Location effects on ripening and grape phenolic composition of eight Carignan vineyards from Maule Valley, Chile. Chil. J. Agr. Res., 78, 139-149.

He F., Liang N., Mu L., Pan Q., Wang J., Reeves M. J., Duan C., 2012. Anthocyanins and Their Variation in Red Wines I. Monomeric Anthocyanins and Their Color Expression. Molecules, 17, 1571-1601.

Hernández M.M., Song S., Menéndez C. M., 2016. Influence of genetic and vintage factors in flavan-3-ol composition of grape seeds of a segregating Vitis vinifera population. J. Sci. Food Agric., 97, 236-243.

IVV, 2017. http://www.ivv.gov.pt/np4/33/np4/362.html (Accessed in 30 August 2018)

Jordão A.M., Ricardo-da-Silva J.M., Laureano O., 1998. Influência da rega na composição fenólica das uvas tintas da casta Touriga Francesa (Vitis vinifera L.) J. Food, 2, 60-73.

Jordão A. M., Correia A. C., 2012. Relationship Between Antioxidant Capacity, Proanthocyanidin and Anthocyanin Content During Grape Maturation of Touriga Nacional and Tinta Roriz Grape Varieties. S. Afr. J. Enol. Vitic, 33, 214-223.

Kennedy J.A., Matthews M.A., Waterhouse A.L., 2000. Changes in grape seed polyphenols during ripening. Phytochemistry, 55, 77-

Kennedy J. A., Hayasaka Y., Vidal S., Waters E., Jones G., 2001. Composition of grapes skins proanthocyanidins at different stages of berry development. J. Agric. Food Chem., 49, 5348-5355.

Kliewer W. M., Torres R. E., 1972. Effect of controlled day and night temperatures on grape coloration. Am. J. Enol. Vitic., 23, 7177 .

Kramling T. E., Singleton V. L., 1969. An estimate of the nonflavanoid phenol in wines. Am. J. Enol. Vitic., 20, 86-92.

Labarbe B., Cheynier V., Brossaud F., Souquet J. M., Moutounet M., 1999. Quantitative fractionation of grape proanthocyanidins according to their degree of polymerization. J. Agric. Food Chem., 47, 2719-2723.

Langbecker M. R., Eckhardt D. P., Cunha W. M., Costa V. B., Gabbardo M., Schumacher R. L., Andrade S. B., 2018. Experience of Cold Maceration on 'Touriga Nacional' Wine Varieties in the Campanha Gaúcha Region, Brazil. J. Exp. Agric. Int., 22, 1-8. 
Lima, M. A. C. de, Leão, P. C. de S., 2015. Teores de compostos fenólicos e potencial antioxidante de uva Syrah sob influência de desponte e desfolha em ciclos produtivos do primeiro semestre. Actas. In: 15th Congresso Latino-Americano de viticultura e enologia e 13th Congresso brasileiro de viticultura e enologia. Embrapa Uva e Vinho, Associação Brasileira de Enologia, Bento Gonçalves, Brasil.

Lima M. S., Leite A. P. S., Sampaio Y. C., Vianello F., Lima G. P. P., 2015. Influences of the Harvest Season on Analytical Characteristics of Syrah Grapes and Wines Produced in the Northeast Region of Brazil. Int. J. Agric. Forestry, 5, 151-159.

Mateus N., Proença S., Ribeiro P., Machado, J. M., De Freitas V., 2001. Grape and wine polyphenolic composition of red vitis vinifera varieties concerning vineyard altitude. Ciênc. Tecnol. Aliment., 2, 102-110.

Mateus, N., Machado, J.M., De Freitas, V., 2002. Development changes of anthocyanins in Vitis vinifera grapes grown in the Douro Valley and concentration in respective wines. J. Sci. Food Agric., 82, 1689-1695.

Monagas M., Gómez-Cordovés C., Bartolomé B., Laureano O., Ricardo-da-Silva J. M., 2003. Monomeric, oligomeric and polimeric flavan-3-ol composition of wines and grapes from Vitis vinífera L. cv. Graciano, Tempranillo and Cabernet Sauvignon. $J$. Agric. Food Chem., 51, 6475-6481.

Mulero J., Pardo F., Zafrilla P., 2009. Effect of principal polyphenolic components in relation to antioxidant activity in conventional and organic red wines during storage. Eur. Food Res.Technol., 229, 807-812.

Mulinacci N., Santamaria A.R., Giaccherini C., Innocenti M., Valletta A., Ciolfi G., Pasqua G., 2008. Anthocyanins and flavan-3ols from grapes and wines of Vitis vinifera cv. Cesanese d'Affile. Nat. Prod. Res., 22, 1033-1039.

\section{Noble C.A., 1994. Bitterness in wine. Physiol. Behav.,56, 1251.}

Obreque-Slier E., Peña-Neira A., López-Solís R., Zamora-Marín F., Ricardo-da-Silva J.M., Laureano O., 2010. Comparative Study of the Phenolic Composition of Seeds and Skins from Carmenére and Cabernet Sauvignon Grape Varieties (Vitis vinifera L.) during Ripening. J. Agric. FoodChem., 58, 3591-3599.

OIV, 2014. Recueil des methodes internacionales d'analyse des vins et des moûts. Office Internacional de la vigne et du vin, Paris, France.

Oliveira C., Barbosa A., Silva Ferreira A.C., Guerra J., Guedes de Pinho P., 2006. Carotenoid profile in grapes related to aromatic compounds in wines from Douro region. J. Food Sci., 71, S001-7.

Oliveira W. P. de, Menezes T. R. de, Oliveira J. B. de, Ribeiro T. P., Pereira G. E., Lima M. dos S., Araújo A. J. de B., Biasoto A. C. T., 2014. Influência do estádio de maturação da uva sobre a composição físico-química e atividade antioxidante do vinho Syrah elaborado no Vale do São Francisco no segundo ciclo produtivo do ano. 317-322. In: 9th Jornada de iniciação científica da Embrapa Semiárido, Petrolina, Brasil

Orduña R. M., 2010. Climate change associated effects on grape and wine quality and production. Food Res. Int., 43, 1844-1855.

Padilha C. V. S., Biasoto A. C. T., Corrêa L. C., Lima M. S., Pereira G. E., 2016. Phenolic compounds profile and antioxidant activity of commercial tropical red wines (Vitis vinifera $\mathrm{L}$.) from São Francisco Valley, Brazil. J. Food Biochem., 41, 1-9.

Pereira G.E., Santos J. de O., Guerra C.C., Alves L.A., 2008. Evaluation of grape and wine quality according to harvest date, in a tropical region in Northeast Brazil. Actas. In: 7th Congrès International des Terroirs Viticoles, Suisse.
Pereira G.E., Araújo A.J.B., Santos de O., J., Oliveira S.V., Nascimento R.L., Quintino C., Vanderlinde R., Lima, L.L.A., 2011. Chemical and aromatic characteristics of Brazilian tropical wines. Acta hortic., 91, 135-140

Revilla E., García-Beneytez E., Cabello F., Martín-Ortega G., Ryan J.M., 2001. Value of highperformance liquid chromatographic analysis of anthocyanins in the differentiation of red grape cultivars and red wines made from them. J. Chromatogr. A, 915, 53-60.

Reynolds A. G., 2010. Managing wine quality. Viticulture and wine quality. vol 1, 120p. CRC press, Canada.

Ribéreau-Gayon P. \& Stonestreet E., 1965. Dosage des tannins du vin rouge et determination de leur structure. Anal. Chim. Acta, 2, $627-631$.

Ribéreau-Gayon P., 1970. Le dosage des composés phénoliques totaux dans les vins rouges. Anal. Chim. Acta, 52, 627-631.

Ricardo-da-Silva J. M., Rosec J. P., Bourzeix M., Heredia N., 1990. Separation and quantitative determination of grape and wine procyanidins by high-performance reversed-phase liquid chromatography. J. Sci. Food Agric., 53, 85-92.

Ricardo-da-Silva J. M., Rigaud J., Cheynier V., Cheminat A. \& Moutounet M., 1991. Procyanidin dimers and trimers from grape seeds. Phytochemistry, 30, 1259-1264.

Ricardo-da-Silva, J. M.; Belchior, A. P.; Spranger, M. I.; Bourzeix M., 1992. Oligomeric procyanidins of three grapevine varieties and wines from Portugal. Sci. Aliments, 12, 223-237.

Rigaud J., Pérez-Ilzarbe J., Ricardo-da-Silva J. M., Cheynier V., 1991. Micro method for the identification of proanthocyanidin using thiolysis monitored by high performance liquid chromatography. J. Chromat., 540, 401-405.

Rodrigues A., Ricardo-da-Silva J.M., Lucas C., Laureano O., 2012. Effect of commercial mannoproteins on wine colour and tannins stability. Food Chem., 131, 907-914.

Roggero J.P., Coen S. \& Ragonnet B., 1986. High performance liquid chromatography survey on changes in pigment content in ripening grapes of Syrah. An approach to anthocyanin metabolism. Am. J. Enol. Vitic., 37, 77-83.

Romero-Cascales I., Ortega-Regules A., López Roca J. M., Fernández-Fernández J. I., Gómez-Plaza E., (2005). Differences in Anthocyanin Extractability from Grapes to Wines According to Variety. Am. J. Enol. Vitic., 56, $212-219$.

Rosatti S. R., Silva E. E. L. de S.; Ristow N. C., Trindade D. C. G. da; Lima M. A. C. de, 2013. Maturação da uva Brbera em dois ciclos de produção orgânica no Semiárido. In: $4^{\text {th }}$ Simpósio brasileiro de pós-colheita de frutas, hortaliças e flores; 7th Encontro Nacional sobre processamento mínimo de frutas e hortaliças. Anais. Ribeirão Preto: USP-Faculdade de Cências Farmacêuticas de Ribeirão Preto, Brasil.

Santos J. de O.; Alencar Y. C. L. de.; Guerra C. C.; Lira M. M. P.; Pereira G. E., 2007. Avaliação do Potencial Enológico de uvas tintas colhidas em duas safras por ano no Vale Submédio São Francisco, Brasil. In: 11th Congresso Latinoamericano de viticultura y enologia, Mendoza, Argentina.

Singleton, V.L., 1995. Maturation of wines and spirits: comparisons, facts, and hypotheses. Am. J. Enol. Vitic. 46, 98112.

Soares J. M., Leão P. C. S., 2009. A vitivinicultura no semiárido brasileiro. Embrapa Informação Tecnológica. Brasilia, Brasil.

Somers T. C., 1971. The polymeric nature of wines pigments. Phytochemistry, 10, 2175-2186. 
Somers T. C. \& Evans M. E., 1977. Spectral evaluation of young red wines: anthocyanin equilibria, total phenolic, free and molecular SO2 «chemical age». J. Sci. Food Agric., 28, 279-287.

Spranger I., Sun B., Mateus A. M., Freitas V., Ricardo-da-Silva J. M. 2009. Chemical characterization and antioxidant activities ofoligomeric and polymeric procyanidin fractions from grape seeds. Food Chem., 108, 519-532.

Sun B. S., Leandro M. C., Ricardo-da-Silva J. M., Spranger M. I., 1998a. Separation of grape and wine proanthocyanidins according to their degree of polymerisation. J. Agric. Food Chem., 46, 13901396

Sun B. S., Ricardo-da-Silva J. M., Spranger M. I., 1998b. Critical factors of the vanillin assay for catechins and proanthocyanidins. $J$. Agric. Food Chem, 46, 4267-4274.

Sun B., Ricardo-da-Silva J. M., Spranger M. I., 2001. Quantification of catechins and proanthocyanidins in several portuguese grapevine varieties and red wines. Cienc. Tec. Vitivinic., 16, 26-34.

Tonietto J., Ruiz V. S., Goméz-Miguel V. D., 2012. Clima, Zonificación y Tipicidad del Vino en Regiones Vitivinícolas Iberoamericanas. 411 p. CYTED, Madrid.
Tyihák, E., kerényi Z., király Z.S., kállay M., 1998. Measurement of procyanidins and resveratrol in Hungarian wines by OPLC and HPLC. 401-403. In: 3th Tannin Conference, Bend, Oregon, USA.

Vilanova M., Campo E., Escudero A., Graña M., Masa A., Cacho J., 2012. Volatile composition and sensory properties of Vitis vinifera red cultivars from North West Spain: Correlation between sensory and instrumental analysis. Anal. Chim. Acta, 720, 104 111

Vilela A., Liquito A., Cosme F., 2016. Caracterização sensorial e fenólica de vinhos tintos monovarietais produzidos com castas tintas cultivadas na região demarcada do Douro. In: Actas 10th Simpósio de Vitivinicultura do Alentejo, Évora-Portugal.

Volschenkla H., Van Vuuren H.J.J., Viljoen-Bloom M., 2006. Malic Acid in Wine: Origin, Function and Metabolism during Vinification. S. Afr. J. Enol. Vitic., 27, 123-136.

Sáenz-Navajas, M. P., Avizcuri, J.M., Ferreira, V., FernándezZurbano, P., 2012. Insights on thechemical basis of the astringency of Spanish redwines. Food Chem., 134, 1484-1493.

Yamane, T.; Shibayama, K., 2006. Effect of changes in the sensitivity to temperature on skin coloration in Aki Queen' grape berries. J. Japan Soc. Hortic. Sci., 75, 458-462. 